Rhode Island College

Digital Commons @ RIC

2016

\title{
Propofol and Emergence Agitation in the Pediatric Population: A Systematic Review
}

\author{
Bevin Doyle \\ Rhode Island College
}

Follow this and additional works at: https://digitalcommons.ric.edu/etd

Part of the Pediatric Nursing Commons

\section{Recommended Citation}

Doyle, Bevin, "Propofol and Emergence Agitation in the Pediatric Population: A Systematic Review" (2016). Master's Theses, Dissertations, Graduate Research and Major Papers Overview. 170.

https://digitalcommons.ric.edu/etd/170

This Major Paper is brought to you for free and open access by the Master's Theses, Dissertations, Graduate Research and Major Papers at Digital Commons @ RIC. It has been accepted for inclusion in Master's Theses, Dissertations, Graduate Research and Major Papers Overview by an authorized administrator of Digital Commons @ RIC. For more information, please contact digitalcommons@ric.edu. 



\section{PROPOFOL AND EMERGENCE AGITATION}

\section{IN THE PEDIATRIC POPULATION:}

\section{A SYSTEMATIC REVIEW}

\section{A Major Paper Presented}

by

Bevin Doyle

\section{Approved:}

Committee Chairperson

Committee Members

Dean, School of Nursing 


\title{
PROPOFOL AND EMERGENCE AGITATION
}

IN THE PEDIATRIC POPULATION:

\section{A SYSTEMATIC REVIEW}

by

\section{Bevin Doyle}

\author{
A Major Paper Submitted in Partial Fulfillment \\ of the Requirements for the Degree of \\ Master of Science in Nursing \\ in
}

The School of Nursing

Rhode Island College

2016 


\begin{abstract}
Emergence agitation (EA) is common among pediatric patients undergoing general anesthesia. Sevoflurane is a volatile anesthetic that is associated with an increased incidence of EA of as high as $80 \%$ in children undergoing surgery. Emergence agitation can cause increased stress in the patient, nurses and caregivers. Agitation experienced by the patient can also increase the risk of self harm, delay medical treatments, damage equipment and ultimately increase the length of stay in the hospital. Current studies lack a consistent method of quantifying and recognizing EA in a standardized manner. The development of the Pediatric Anesthesia Emergence Delirium (PAED) scale provided a reliable and accurate tool to assess EA in pediatric patients. Propofol has been used in sub-hypnotic doses to reduce both the incidence and severity of EA. The purpose of this systematic review was to examine the current literature to determine if there is an effect on PAED scores of patients that undergo general anesthesia with sevoflurane after receiving an intravenous dose of propofol prior to emergence. This systematic review was created using guidelines put forth by both PRISMA and CONSORT. A literature review was performed and data were collected from each study. A cross study analysis was performed using data collection tables created by the author of this systematic review. Propofol was found to decrease both the incidence and severity of EA in pediatric patients undergoing ophthalmic, inguinal hernia repair, adenostonsillectomies and non-painful procedures such as MRI scans. By incorporating the use of propofol in the anesthetic plan for pediatric patients, anesthesia providers will be able to decrease the incidence the EA and its' associated adverse outcomes.
\end{abstract}




\section{Acknowledgements}

I would like to thank my friends and family that have helped support me through this arduous journey. A special thank you goes out to my husband Jeff who should receive an honorary anesthesia degree for the stress I have put him under. But the most special thank you of them all is reserved for my father, who has given me the motivation and determination needed to make this possible. You have been, and will continue to be the smartest, kindest, most wonderful person on this planet. This has been all for you. 


\section{Table of Contents}

Background/Statement of the Problem ....................................................................... 1

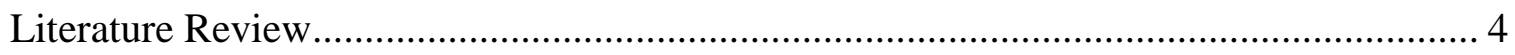

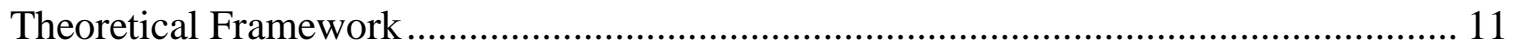

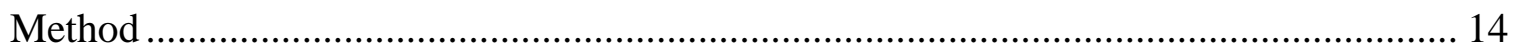

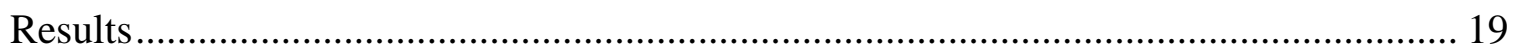

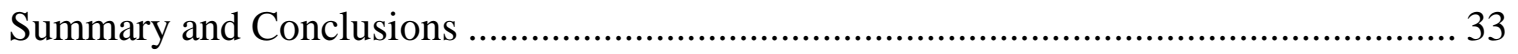

Recommendations and Implications for Advanced Nursing Practice ........................... 39

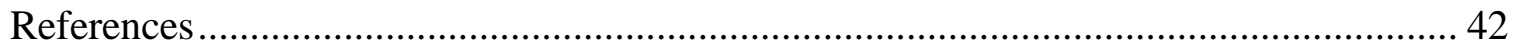

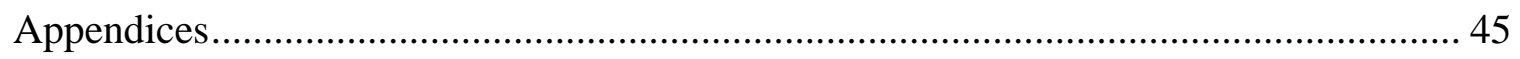


Propofol And Emergence Agitation In The Pediatric Population: A Systematic Review

\section{Background/Statement of the Problem}

Approximately four million children undergo general anesthesia each year in the United States (Miller et al., 2015). One of the most common inhalation anesthetic agents used in pediatric general anesthesia is sevoflurane. Sevoflurane is a volatile anesthetic that allows for a rapid induction as well as timely emergence related to its low blood gas coefficient. It is these same reasons that may also make sevoflurane one of the leading causes of emergence agitation in the pediatric population. Sevoflurane has been associated with an incidence rate of emergence agitation as high as $80 \%$ in children (Kim, Yoon, Lim \& Yoon, 2011).

Emergence agitation (EA) can occur after general anesthesia and includes behaviors such as crying, disorientation, excitement and delirium (Miller et al., 2015). These children can suffer from paranoid delusions and display restlessness that can quickly escalate to combative behavior (Vlajkovic \& Sindjelic, 2007). Although the condition is self-limiting, the increased risk of patient injury and stress experienced by both the patient and their care giver(s) have made the limitation of EA a focus of research (Kim, Moon, Kim \& Lee, 2012). These patients are also at a greater risk of disrupting medical treatments and equipment, requiring extra nursing care and ultimately requiring a longer length of stay (Vlajkovic \& Sindjelic, 2007).

There are many tools available for both the reporting and rating of EA. Due to the questionable validity and reliability of the tools that were presently available, the pediatric anesthesia emergence delirium scale (PAED) was developed (Sikich \& Lerman, 2004). The scale consists of five scale items by which the patient is evaluated. These 
items include; eye contact, purposeful actions, awareness of surroundings, restlessness and consolability (Sikich \& Lerman) (Figure 1).

\begin{tabular}{ll}
\hline & \multicolumn{1}{c}{ Score } \\
\hline The child makes eye contact with the caregiver & $4:$ not at all \\
The child's actions are purposeful & $3:$ just a little \\
The child is aware of his/her surroundings & $2:$ quite a bit \\
& $1:$ very much \\
& $0:$ extremely \\
\hline The child is restless & $0:$ not at all \\
The child is inconsolable & $1:$ just a little \\
& $2:$ quite a bit \\
& $3:$ very much \\
& $4:$ extremely \\
\hline
\end{tabular}

Figure 1. PAED scoring tool

Each item is scored numerically between 1 and 4 and the sums of the individual scores comprise the total PAED score. The degree of emergence agitation is directly correlated with increasing scores. "A score of $\geq 4$ (from crying and difficult to console to wild thrashing) for a five or more minute duration despite active calming efforts is regarded as indicative of emergence delirium" (Reduque \& Verghese, 2012, p.1). The internal consistency of the scoring tool was 0.89 along with a reliability rating of 0.84 (95\% confidence interval, 0.76-0.90) (Sikich \& Lerman, 2004). The authors developed three hypotheses to further validate the PAED scale. The first hypothesis was supported, with the scores having a negative correlation with the age of the patient $(r=-0.31$, $\mathrm{P}<0.04)$. The second hypothesis also showed a negative correlation with the score but in relation to the awakening time $(\mathrm{r}=-0.5, \mathrm{P}<0.001)$. The PAED scores were found to be higher after the administration of sevoflurane compared to that of halothane $(\mathrm{P}<0.008)$ with a sensitivity of 0.64 (Sikich \& Lerman).

Many medications have been used prophylactically to decrease the incidence of EA including fentanyl, ketamine, midazolam and most recently dexmedetomidine 
(Precedex). Propofol has also been used as an adjunct medication for the prevention of EA. Propofol is a hypnotic sedative that achieves its anesthetic effect by inhibiting GABA receptors in the central nervous system (Nagelhout \& Plaus, 2014). It is often used as an induction agent for pediatric anesthesia when given intravenously at a dose of 2-3 mg/kg (Nagelhout \& Plaus). Propofol used at sub-hypnotic doses (1 mg/kg) at the end of general anesthesia has been found to decrease the incidence of EA when sevoflurane was used as the primary inhalation anesthetic (Messieha, 2013).

The purpose of this paper was to present a systematic review conducted to determine if the administration of propofol decreases the incidence of EA as evidenced by decreased PAED scores after the use of sevoflurane during general anesthesia in the pediatric population.

Next, the review of the literature will be presented. 


\section{Literature Review}

Emergence agitation is a global phenomenon within the pediatric patient population. Key, Rich, DeCristofaro and Colllins (2010) conducted a literature review with the goal of evaluating the incidence of EA in children that were administered anesthesia in three categories: sevoflurane alone, propofol as an adjunct to sevoflurane and propofol used as a total intravenous anesthesia technique. The literature review examined a total of 10 randomized control trials. Three trials used sevoflurane as the sole anesthetic, five used propofol for total intravenous anesthesia and the final two studies used propofol as an adjunct anesthetic at the end of the surgery. A total of 1172 children aged 1- 6 years old were included in the studies. A higher incidence of EA within the sevoflurane only studies was reported as compared to those patients that received propofol either at the end of the surgery or as part of a total intravenous anesthetic. Children that underwent procedures were found to have EA rates ranging from $50-60 \%$ when sevoflurane was given as the sole anesthetic agent. Emergence agitation incidence rates dropped to $4.8 \%-19 \%$ and $3.7 \%-11 \%$ with the propofol adjunct and TIVA groups respectively.

Although the literature review conducted by Key et al. (2010) could demonstrate a direct correlation between the administration of propofol and the decreased incidence of EA, there were many limitations that affected the overall strength of the findings. One of the key discrepancies occurring throughout the review is the lack of a consistent measurement tool of emergence agitation. Some studies used a four-point scale; others used the PAED tool while others were not specified. This lack of consistency can affect the validity of the review. The information lacking in this particular literature review 
inspired the problem statement for this systematic review by limiting the EA tool to include only the PAED scale.

\section{Studies Using the PAED Scale to Measure EA in Pediatric Subjects}

Inguinal hernia repair. There were several randomized control trials that utilized the PAED as their primary tool for measuring pediatric emergence delirium. One such trial compared the administration of both propofol and fentanyl in the effective prevention of EA related to sevoflurane anesthesia (Kim et al., 2012). This randomized double blinded control trial involved 205 children aged $18-72$ months of age. All of the children were scheduled to undergo an inguinal hernia repair and were considered in good health with ASA ratings of no greater than II. Each of the participants were randomly assigned to either the propofol group (group P: $n=69$ ), the fentanyl group (group F: $\mathrm{n}=66$ ), or the placebo group, which received saline (group $S: n=70$ ). At the completion of the surgery, each participant received the dosing of assigned medication: propofol dosed at $1 \mathrm{mg} / \mathrm{kg}$; fentanyl dosed at $1 \mu \mathrm{g} / \mathrm{kg}$; and $2 \mathrm{ml}$ of saline. Upon arrival to the post-anesthesia care unit (PACU) the PAED scale was used every five minutes for the first 30 minutes after arrival on the unit. The mean PAED score was 4.3 for group $\mathrm{P}$ and 4.9 in group $\mathrm{F}(P=0.682)$, which were lower than the mean of 9.0 in group $\mathrm{S}(P<$ 0.001). This trial demonstrated a significant decrease in the PAED score for the pediatric patients that received a sub-hypnotic dose of both the propofol and fentanyl. Limitations of the study include the lack of variety of procedures performed which decreases the generalizability of the results of the study. All of the patients underwent an inguinal hernia repair. "Emergence agitation is different depending on the type of surgery and is 
known to be higher in otorhinolaryngological or ophthalmological procedures" (Kim et al., p.279).

Opthalmic procedures. Strabismus correction is a commonly performed ophthalmologic surgical procedure in the pediatric population. Aouad et al. (2007) performed a randomized double-blind study that aimed to determine if a single dose of propofol given at the end of sevoflurane anesthesia would decrease the incidence of EA after strabismus surgery. Eighty children aged 2-6 years that were scheduled for elective strabismus surgery were selected for the study. Children were randomly assigned to the propofol group $(n=41)$ and the saline placebo group $(n=39)$. The propofol group received $1 \mathrm{mg} / \mathrm{kg}$ at the end of surgery where as the placebo group received an equal volume of saline.

The PAED scores were obtained and the mean scores of the propofol group $(8.6 \pm$ $3.9 ; P=0.004)$ were much lower than the saline group $(11.5 \pm 4.5 ; P=0.004)$. The scores were generally higher in relation to those obtained during the trial involving the inguinal hernia procedures, but still demonstrated a reduction in the appearance and severity of EA. Limitations of this study involved the use of the PAED tool. One of the evaluation items included making eye contact with the caregiver that would have been hard to determine with unilateral ocular dressings.

Although not as common as strabismus surgery, cataract surgery is also performed in the pediatric population. A study conducted by Chen, Li, Hu \& Wang (2010) set forth to determine if the use of sub-hypnotic doses of propofol, ketamine or midazolam would decrease the incidence of EA after cataract surgery performed under a sevoflurane anesthetic using the PAED tool. A total of 120 children aged 1-7 were 
selected to participate. All of the patients were scheduled for an elective cataract removal procedure and were randomly assigned to one of three postoperative groups $(n=40)$ : midazolam (MF) group, propofol (PF) group and the ketamine (KF) group. At the end of the procedure, as the sevoflurane was being discontinued the patients received a dose of medications based on which group they were assigned to. The MF group received $0.05 \mathrm{mg} / \mathrm{kg}$ of midazolam, the $\mathrm{PF}$ group received $1 \mathrm{mg} / \mathrm{kg}$ of propofol and the $\mathrm{KF}$ group received $0.25 \mathrm{mg} / \mathrm{kg}$ of ketamine. The patients were then evaluated for EA in the PACU at 5,10, 15 and 30-minute intervals using the PAED assessment tool. The peak scores were recorded and a value of $\geq 10$ was considered indicative of EA.

The number of patients with a PAED score $\geq 10$ in the KF group were 18 (45\%) and the number of patients that had scores $\geq 15$ were $10(25 \%)$. The MF and PF group demonstrated a much lower percentages of PAED scores $\geq 10$ with only $15 \%(\mathrm{P}=$ $0.0034)$ and $20 \%(P=0.017)$ respectively. The PAED scores that were $\geq 15$ within the MF group were only $2.5 \%(P=0.0035)$ and the $\mathrm{PF}$ group had only $7.5 \%(\mathrm{P}=0.0339)$ of the patients with an elevated score.

Although this study illustrates a clear reduction in the PAED score in those patients that received a sub-hypnotic dose of propofol, there were also limitations. The lack of a placebo group weakens the study design. The author stated that the decision to not include a placebo group was based on ethical reasons and considerations (Chen et al.).

Adenotonsillectomy procedures. Adenotonsillectomy procedures are commonly performed in the pediatric population. A randomized control trial conducted by Lee et al. (2010) set forth to determine if a single dose of propofol given at the end of anesthesia 
would decrease the incidence and severity of EA when sevoflurane was administered. Ninety children between the ages of 3-8 years were selected to participate in the study. All of the participants were scheduled for an elective adenotonsillectomy and were randomly assigned into two groups. One group received propofol at $1 \mathrm{mg} / \mathrm{kg}(\mathrm{n}=45)$ and the other group received saline at $0.1 \mathrm{ml} / \mathrm{kg}(\mathrm{n}=45)$ at the end of the surgery. Emergence delirium and agitation was then measured using the PAED scale at 5 (T5), 15 (T15) and 30 (T30) minute intervals after emergence.

The incidence of EA in the propofol group was lower when compared to the saline group at the T5, T15 and T30 marks. The mean scores of the PAED scale at T5, $\mathrm{T} 15$ and $\mathrm{T} 30$ were $12.6 \pm 4.6,8.2 \pm 3.8$, and $5.0 \pm 3.1$ respectively in the propofol group while $13.8 \pm 4.7,8.0 \pm 3.9$ and $4.5 \pm 3.1$ in the saline group. Although there was not a significant reduction in the incidence or severity of EA at the T5 or T15 time marks, the effectiveness was more clearly demonstrated at T30. The authors did not recommend the administration of propofol after adenotonsillectomy surgery and stated that further studies were needed in order to better differentiate between post-operative pain and agitation (Lee et al.).

Another study conducted by Ali \& Abdellatif (2013) also focused on the prevention of sevoflurane related EA in children undergoing adenotonsillectomy and the effectiveness of propofol and dexmedetomidine as preventative medications. A total of 120 children aged 2-6 years old were selected that had been scheduled for an elective adenotonsillectomy. The patients were randomly assigned to one of three groups: those that received $10 \mathrm{ml}$ of $0.9 \%$ normal saline (Group C, $\mathrm{n}=40$ ); those that received $1 \mathrm{mg} / \mathrm{kg}$ propofol (Group P, $\mathrm{n}=40$ ); and those that received $0.3 \mu \mathrm{g} / \mathrm{kg}$ of dexmedetomidine (Group 
$\mathrm{D}, \mathrm{n}=40$ ). All of the study groups received their doses of medication five minutes prior to the conclusion of the procedure. The PAED scores were assessed at 5 (T5), 10(T10) and 15(T15) minute intervals. The incidence of EA within Groups P and D were lower compared to that of Group C. At T5, Group C (saline) had a mean PAED score of $8.4 \pm$ 4.5, Group P (propofol) had a mean score of $6.6 \pm 3.2$, and Group D (dexmedetomidine) had a mean score of $5.2 \pm 2.9$. Compared to group D, the incidence and severity of EA in group $\mathrm{P}$ were significantly higher at $\mathrm{T} 0, \mathrm{~T} 5$, and $\mathrm{T} 15$ but not $\mathrm{T} 30$. This trial demonstrated that although propofol reduces the overall PAED scores when compared to a placebo, it also has a higher incidence of EA when compared to other adjuvants such as dexmedetomidine. The effectiveness of propofol didn't exceed that of dexmedetomidine until 30 minutes after the emergence from anesthesia.

Non-painful procedures. The previous trials all include surgical procedures that are both stimulating and associated with a significant amount of post surgical pain. One randomized control trial that was conducted by Abu-Shahwan (2008) focused on the effects of propofol on EA after the administration of sevoflurane anesthesia for nonpainful procedures. 84 children between the ages of 2-7 years old were selected for the study. The patients were all scheduled to undergo a magnetic resonance imaging (MRI) study that required general anesthesia. No surgical interventions were necessary and there were no expectations of peri- or post-procedure pain. The patients were randomly assigned to either group $\mathrm{P}$ which received $1 \mathrm{mg} / \mathrm{kg}$ propofol prior to emergence or group $\mathrm{S}$ which received only a placebo dose of saline. The PAED scoring system was used during the first 30 minutes after emergence for each of the groups. The peak PAED 
scores for the propofol group was 7 compared to the peak score of 13 of the saline group. Both the groups' peak PAED scores were associated with a $\mathrm{P}$ value $<0.05$.

A more recent randomized control trial conducted by Costi et al. (2015) involved pediatric patients scheduled to complete MRI procedures under general anesthesia. A total of 230 children aged from 1 to 12 years old where randomly assigned to either receive a propofol bolus of $3 \mathrm{mg} / \mathrm{kg}$ over 3 minutes or no intervention at the end of general anesthesia comprised of inhaled sevoflurane. The group receiving the propofol bolus had a decreased incidence of EA as well lower PAED scores. The percentage of patients presenting with EA in the propofol group, compared to that of the placebo group were $7 \%$ and $29 \%$ respectively with a confidence interval of $0.12-0.52$ and $P<0.001$. Although this study did not use a sub-hypnotic dose of propofol, the administration of $3 \mathrm{mg} / \mathrm{kg}$ over a period of three minutes had a significant effect on the incidence of EA based on PAED scores. This trial was included as a discussion point for the need for further research regarding the range of dosages and the concurrent effects on EA.

In summary, the administration of propofol prior to emergence from sevoflurane anesthesia decreased the PAED scores in all of the randomized control trials reviewed. Next, the theoretical framework utilized for this systematic review will be discussed. 


\section{Theoretical Framework}

The emphasis on evidence based practice and its influence on the development of new clinical guidelines have made systematic reviews and meta-analyses the cornerstone of present day healthcare. Systematic reviews can provide the basis for changes in the delivery of care and therefore the strength and validity of their content must be scrutinized. The preferred reporting items for systematic reviews and meta-analyses (PRISMA) statement was used to guide the creation of this systematic review (Moher, Liberati, Tetzlaff \& Altman, 2009). The PRISMA guidelines were created in order to not only improve the quality of review reporting, but also to assist in the assessment of a systematic review's strengths and weaknesses. Both the PRISMA checklist and flow diagram were used to insure the creation of a strong and relevant systematic review.

The PRISMA checklist (Appendix A) contains 27 evidence-based items that were used in developing and reporting this systematic review (Moher et al., 2009). These items included factors such as title, abstract, introduction, methods, data collection processes, synthesis of results, bias reporting and limitations. While creating this systematic review the author referred to the checklist and insured that all items were addressed within the report.

The PRISMA tool also includes a flow diagram, illustrated on the following page (Figure 2), that assisted in the process and organization of the literature review. The flow 


\section{PRISMA 2009 Flow Diagram}
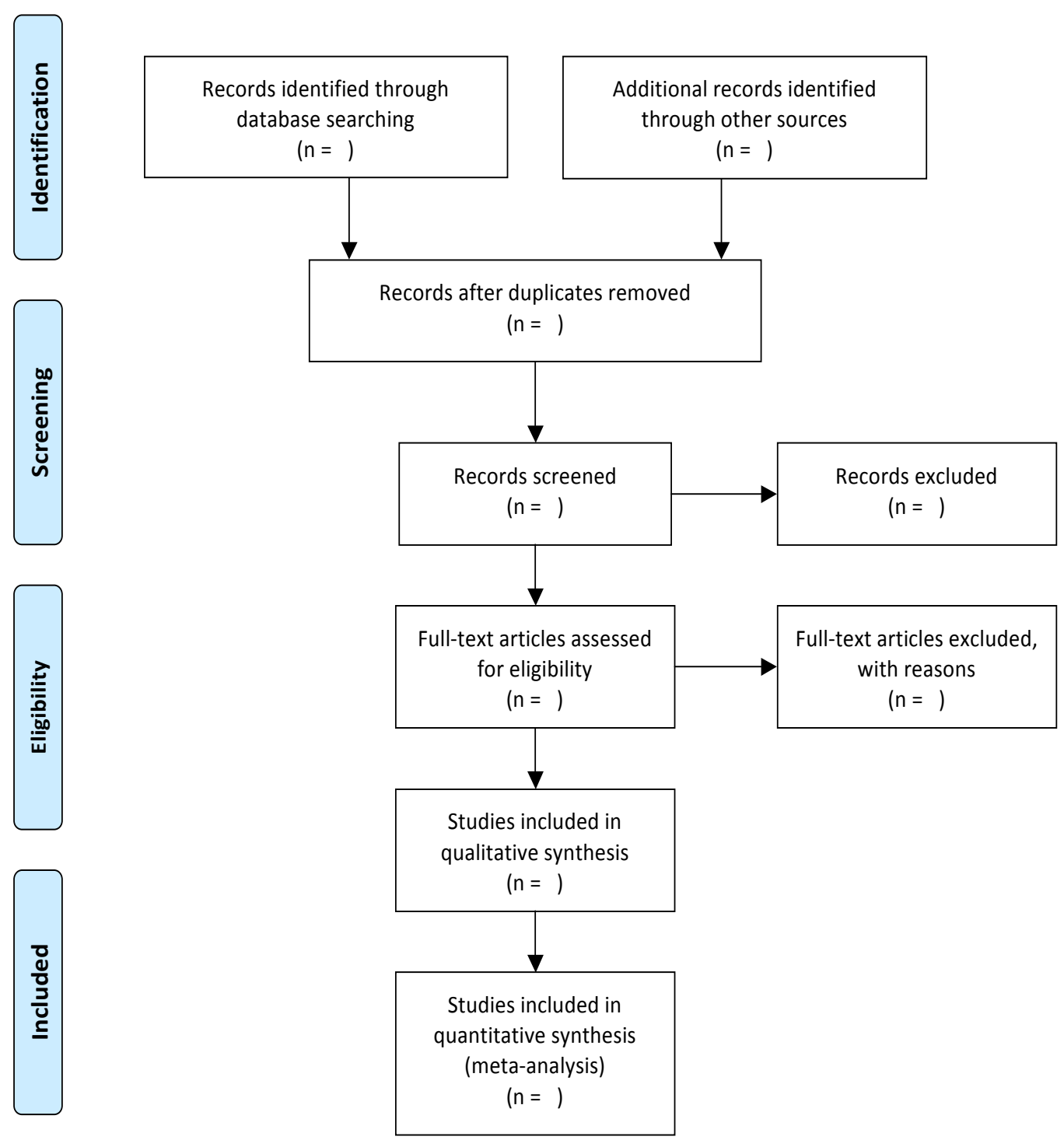

Figure 2. PRISMA Flowchart (Moher et al., 2009) 
chart organized the search results based on both inclusion and exclusion criteria determined by the author of the review. The end result provided a final number of studies that were included in the systematic review. The PRISMA guidelines provided a framework in which the author could create a relevant and strong systematic review. In addition to the PRISMA checklist and flowchart, the author also utilized the consolidated standards of reporting trials framework (CONSORT, 2010) (Appendix B) checklist to further evaluate and insure the quality of the randomized control trials that were reported. The CONSORT checklist was designed to specifically examine randomized control trials and evaluate their strengths, weaknesses and limitations. It is also utilized to identify sources of bias. This checklist was used for the critical appraisal for each of the articles used for the creation of this systematic review. There are 25 items on the checklist including items such as trial design, eligibility of participants, sample size determination, randomization methods, blinding, limitations, statistical methods and generalizability.

All of the randomized clinical control trials included within this systematic review were also evaluated across the studies. The PAED scores, emergence times, discharge times and adverse effects were compared among the control and interventional groups within the seven trials. This information was recorded within a data collection table created by the author of this review to compare the effects of propofol on these outcomes.

Next, the methods section will be presented and discussed. 


\section{Method}

\section{Purpose}

The purpose of this paper was to present a systematic review conducted to determine if the administration of propofol decreases the incidence of EA as evidenced by decreased PAED scores after the use of sevoflurane during general anesthesia in the pediatric population.

\section{Inclusion/Exclusion Criteria}

Inclusion criteria consisted of randomized clinical trials, meta-analyses or systematic reviews conducting in the last 10 years that included the following: pediatric surgical population (ages six months to 18 years); elective surgical procedures; use of sevoflurane for general anesthesia, use of PAED as assessment tool for measuring emergence agitation, ASA I-III; and propofol given at or near the end of the procedure (within 15 minutes).

Exclusion criteria included: use of alternate tools for assessment of EA; studies conducted in foreign languages; literature over 10 years old; ASA IV patients or emergent cases; adult patients; use of isoflurane or desflurane; conscious or moderate sedation; propofol given at the beginning of the procedure or over 30 minutes prior to the conclusion of surgery; and studies that consisted of less than 20 subjects.

\section{Search Strategy}

The literature search was performed using both the Pubmed and Medline databases. An initial generalized search was conducted by using the keyword "Propofol" within each database. A total of 2730 articles were located within Pubmed and an additional 17,308 articles were available through Medline. The search was narrowed by the addition of a second keyword "Emergence Agitation". The results from both Pubmed 
and Medline were drastically reduced to 56 and 54 items respectively. A final filter was placed on the search limiting the publication of the literature between the years of 2005 and 2015, as well as restricting the results to those articles that focused on human subjects only, were written in English and published in peer reviewed journals. The final search yielded 38 articles from Pubmed and 30 articles from Medline.

\section{Data Collection}

The randomized control trials (RCT) were reviewed and relevant data collected for further analysis. In an effort to analyze the influence of not only propofol on PAED scores, but also other variables presented within the randomized control trials, two tables were created for data collection and comparisons across studies.

The first table was designed to record basic information about the randomized control trials including author, year of study, number of patients included in the study, ages of participants, gender, ASA score, procedure performed, procedure duration and allocation of participants into control and interventional groups (Table 1).

Table 1

Data Collection Sheet \#1

\begin{tabular}{|l|l|l|l|l|l|l|l|l|}
\hline Author, Year & $\begin{array}{l}\text { \# Pt in } \\
\text { Trial }\end{array}$ & $\begin{array}{l}\text { Ages } \\
(\mathrm{yr})\end{array}$ & $\mathrm{M} / \mathrm{F}$ & ASA & Procedure & $\begin{array}{l}\text { Duration } \\
\text { (min) }\end{array}$ & $\begin{array}{l}\text { Propofol } \\
\text { Group }\end{array}$ & $\begin{array}{l}\text { Interventional } \\
\text { Group }\end{array}$ \\
\hline & & & & & & & & \\
\hline & & & & & & & & \\
\hline & & & & & & & & \\
\hline & & & & & & & & \\
\hline & & & & & & & & \\
\hline & & & & & & & & \\
\hline & & & & & & & & \\
\hline
\end{tabular}

A second table was designed to collect data on other variables that may have influenced PAED scores within the trials including interventional dose and timing of the 
administration, timing of obtainment of PAED scores, parental presence, timing of emergence and discharge from PACU as well as any adverse events (Appendix C).

\section{Critical Appraisal}

The CONSORT method (Appendix B) was used to critically appraise the randomized control trials included within this systematic review. The 25 -item checklist was used to identify strengths, weaknesses, biases and limitations of each of the trials. The items include identification of trial design, eligibility and selection of participants, settings, sample size, interventions, randomization methods, limitations and funding.

A flow diagram designed by CONSORT, illustrated in Figure 3 on the next page, was utilized to further assess and determine the overall strength and weaknesses of the randomized control trials. The diagram focuses on the sample size, randomization, allocation of participants and those participants that may have been lost during follow up and analysis. A flow diagram was completed for each randomized control trial used for this systematic review

A table was created in order to facilitate the collection and organization of data concerning the strengths, methods of sampling, randomization, funding and limitations of each randomized clinical trial (Appendix D). These were constructed through the information obtained by utilizing both the PRISMA and CONSORT checklists and flow diagrams. This method provided a more succinct and valuable assessment tool. 
CONSORT 2010 Flow Diagram

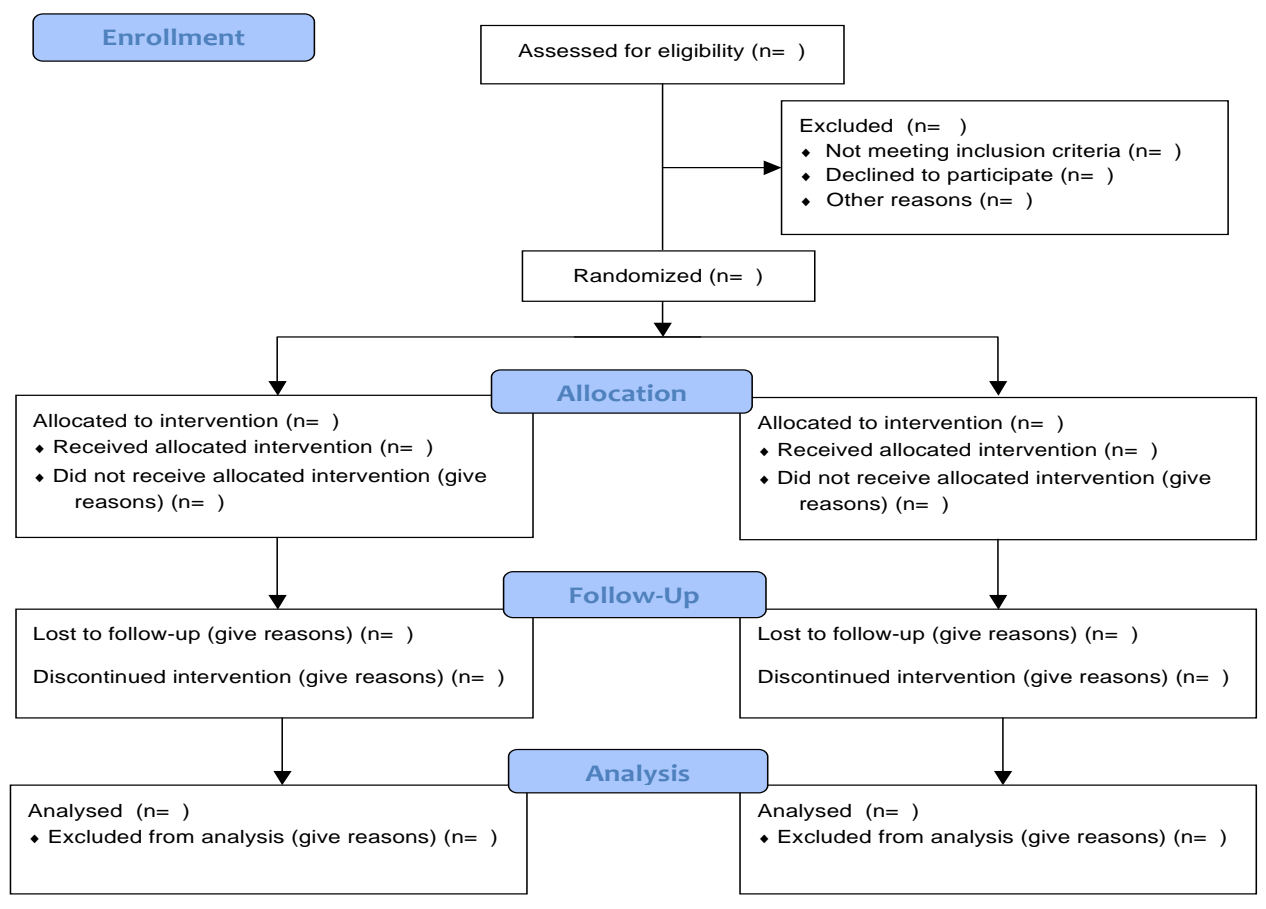

Figure 3. CONSORT Flow Diagram (CONSORT, 20 


\section{Data Synthesis \& Cross Study Analysis}

The data collection tools created to extract information from the randomized control trials were utilized in both synthesizing the data and analyzing the data across the studies. A cross study analysis was performed that evaluated the effects of propofol on overall PAED scores, emergence times, discharge times and the development of any adverse events that occurred during the study. The data were entered in the table depicted below (Table 2) and the results will be described later in this paper.

Table 2

Cross Study Analysis

\begin{tabular}{|l|l|l|l|l|}
\hline $\begin{array}{l}\text { Author, Year } \\
\text { Type of } \\
\text { Procedure }\end{array}$ & $\begin{array}{l}\text { Propofol Group } \\
\text {-affect on } \\
\text { PAED scores }\end{array}$ & $\begin{array}{l}\text { Propofol Group } \\
\text { Affect on } \\
\text { Emergence Times }\end{array}$ & $\begin{array}{l}\text { Propofol Group } \\
\text { Affect on } \\
\text { Discharge Time }\end{array}$ & $\begin{array}{l}\text { Adverse } \\
\text { Events }\end{array}$ \\
\hline & & & & \\
\hline & & & & \\
\hline & & & & \\
\hline & & & & \\
\hline
\end{tabular}

Next, the results section will be discussed. 


\section{Results}

The PRISMA flowchart (Appendix E), along with the inclusion and exclusion criteria previously mentioned, were used to further eliminate and select articles that were appropriate for the systematic review. There were several duplicate articles found within both the databases, and after their elimination, a total of 32 articles remained for review. The abstracts of these articles were reviewed for evidence of exclusion criteria that would deem them not appropriate for the systematic review. This process eliminated a total of 10 articles. The remaining 22 articles were reviewed in their entirety for relevance and selected for the systematic review based on both the exclusion and inclusion criteria. This final elimination process omitted 14 articles from the search results, leaving a total of 8 articles for inclusion within the systematic review.

Of the eight articles that remained, seven were randomized control trials with only one literature review that was relevant to the purpose of this systematic review. The seven randomized control trials met the inclusion criteria and were used in the creation of this systematic review. The following is a summary of results obtained from the data collection sheets. The results are organized per similar procedures performed as previously categorized in the literature review section.

\section{Non-Painful Procedures}

The randomized control trial conducted by Abu-Shahwan (2008) (Appendix F1a, 2a) included 83 pediatric patients ranging from 2-7 years old with a 1:1 male to female ratio. Patients underwent outpatient MRI procedures and all had ASA scores below 2. The mean duration of the procedures was 73 minutes. The patients were induced using a mask inhalation method utilizing a combination of sevoflurane and 
nitrous oxide. A laryngeal mask airway with pressure support ventilation was used during the procedure. Anesthesia was maintained using $2 \%$ sevoflurane and a mixture of $60 \%$ nitrous oxide and $40 \%$ oxygen mixture. At the completion of the procedure the propofol group $(n=42)$ received $1 \mathrm{mg} / \mathrm{kg}$ of propofol intravenously and the saline group $(n=41)$ received $0.9 \%$ normal saline in an unspecified amount. The LMA was removed once regular respirations were obtained and before the patient fully emerged from the anesthetic. Emergence occurred in the post recovery area with parents present at the discretion of a recovery nurse. There was no additional data provided indicating the percentage of patients with parents present at emergence. The degree of agitation was measured using the PAED scoring system upon awakening and then every 5 minutes during the first 30 minutes after admission to the recovery area. The peak PAED score was recorded for evaluation. The propofol group had a peak PAED score of $7(\mathrm{P}<0.05)$, where as the saline group had a peak score of $13(\mathrm{P}<0.05)$. There were no adverse physiologic events noted for either group of patients. Emergence (eye opening) times for the propofol and saline groups were $9 \pm 3.4$ minutes and $7 \pm 2.7$ minutes respectively. The time to discharge for the propofol group was $31.21 \pm 6.1$ minutes and the saline group required $33.4 \pm 5.8$ minutes before being discharged from the recovery area.

The study conducted by Abu-Shahwan (Appendix F-3a) was able to collect significant data, despite a small sample size, with PAED scores that were obtained with a $\mathrm{P}$ value of $<0.05$. The PAED scores were further compared between the groups using the Mann-Whitney U-test and Fisher's exact test. Although the results are generalizable to a vast majority of pediatric patients, the lack of specified timing of interventions and data 
concerning the initial assessment and recruitment of patients weakened the results of the study.

Using the CONSORT framework, a flow diagram was constructed that assessed the sample size, eligibility, exclusion criteria, randomization and attrition of the participants within the study (Appendix G-1). There was a substantial amount of data not reported within the study. Data including initial sample size, number of patients excluded prior to randomization and the associated rationale were not available. There was just one exclusion reported of a patient within the control group who had received propofol during the study.

Costi et al. (2015) (Appendix F-1b, 2b) also conducted a randomized control trial focusing on pediatric patients undergoing MRI procedures. The study included 218 patients ranging from the ages of $1-12$ years of age. All the participants were an ASA 2 or less. 109 participants were randomly assigned to a control group and the remaining One hundred and nine participants were administered $3 \mathrm{mg} / \mathrm{kg}$ of propofol at the completion of the MRI. Oral midazolam $(0.5 \mathrm{mg} / \mathrm{kg})$ was administered pre-operatively and the patient was either induced with sevoflurane and oxygen or with propofol intravenously. An LMA was placed and anesthesia maintained with an unspecified concentration of sevoflurane and nitrous oxide. The PAED scores were obtained upon arrival to the PACU and at 5-minute intervals for the first 30 minutes. Peak PAED scores and ranges for each group were reported. The control group had a peak PAED score of $10(\mathrm{P}<0.001)$ with a range of 6-13. The group that received propofol had a peak PAED score of $6(\mathrm{P}<0.001)$ with a range of $2-10$. The average emergence times of the propofol and control group were $17 \pm 10$ minutes and $9 \pm 10$ minutes respectively $(\mathrm{P}<0.001)$. 
The average discharge time from the PACU was $95 \pm 38$ minutes for the propofol group and $99 \pm 48$ minutes for the control group $(\mathrm{P}=0.573)$. Whether there was parental presence during recovery was not specified. Laryngospasm was noted in three patients in the control group and only one patient from the propofol group. No other adverse events were reported.

There were both strengths and weaknesses noted within the study conducted by Costi (Appendix F-3b). The study reported data that included significantly reduced PAED scores within the propofol group with a $\mathrm{P}$ value of $<0.001$. These data were further analyzed using the Shapiro-Wilks test. Limitations of this trial include administration of a higher dose of propofol $(3 \mathrm{mg} / \mathrm{kg})$ than that of the other trials within this systematic review, as well as some participants being administered propofol upon induction despite being part of the control group.

The study conducted by Costi (Appendix G-2) reported their participant selection and allocation using the CONSORT flow diagram. Twelve participants were excluded from the initial selection due to refusal to participate. A large sample size consisting of 230 participants completed the study and were included in the final analysis.

\section{Adenotonsillectomy procedures}

The trial conducted by Ali and Abedellatif (2013) (Appendix F-1c, 2c) compared the effects of dexmedetomidine and propofol on the severity of EA within a pediatric population undergoing adenotonsillectomy procedures. The study included 120 patients with ages ranging from 2-6 years old. There were 69 males and 51 females that completed the trial, all of which had an ASA score of 2 or less. The procedures had a mean duration of 58 minutes. The patients were administered oral midazolam $(0.5 \mathrm{mg} / \mathrm{kg})$ 
pre-operatively. General anesthesia was induced with mask inhalation with sevoflurane and nitrous oxide. Endotracheal intubation was performed with the aid of rocuronium $(0.6 \mathrm{mg} / \mathrm{kg})$ and general anesthesia was maintained with sevoflurane (2-3\%) combined with a $60 \%$ concentration of nitrous oxide and $40 \%$ oxygen mixture. Antiemetic medications including dexamethasone and paracetamol were administered perioperatively. Reversal with atropine and neostigmine was utilized prior to extubation. Five minutes before the conclusion of the surgery 40 patients were administered $1 \mathrm{mg} / \mathrm{kg}$ propofol intravenously. A control group consisting of 40 patients was given $10 \mathrm{ml}$ of normal saline and the remaining 40 patients received $0.3 \mathrm{mg} / \mathrm{kg}$ of dexmedetomidine. Each intervention was administered over a period of five minutes. PAED scores were obtained at four different time intervals; upon arrival to the recovery areas and then at five, 15 and 30 minute intervals.

The saline group had the overall highest PAED scores with an average of $13.7 \pm$ at the time of the arrival to the recovery room, and 7 patients had PAED scores greater than 15. Those patients that received propofol prior to emergence had an average PAED score of $11.6 \pm 3.8$ and only two patients with PAED scores greater than 15 . The precedex group had the lowest PAED scores with an average of $9.8 \pm 3.5$ upon arrival to the PACU with only two patients with PAED scores greater than 15. All participants had parental presence once arriving to PACU. The emergence times were the greatest among the propofol group at 12.3 minutes compared to the saline and precedex groups at 10.7 minutes and 10.9 minutes respectively. Discharge from the PACU times were the greatest among the precedex groups at 40.1 minutes, followed by the propofol group at 38.5 minutes and the saline group which averaged a time of 10.7 minutes. Vomiting 
occurring in five patients receiving propofol, four that received precedex and three that were part of the saline interventional group. No other adverse events were noted.

The trial conducted by Ali and Abedellatif (Appendix F-3c) reported a significant decrease in the PAED scores of both those participants that received propofol and in those that received precedex. Both results were reported with a $\mathrm{P}$ value of $<0.05$. The larger sample size and the frequency of the procedure performed in the pediatric population strengthened the data collected for this systematic review. Other than the lack of information concerning the initial participant selection and exclusion data, this study had very few limitations.

Using the CONSORT framework a flow diagram was constructed in an attempt to assess the sample size, eligibility, exclusion criteria, randomization and attrition of the participants within the study (Appendix G-3). The data within the study were not specific concerning the original numbers of participants the sample was selected from nor were specific reasons for exclusions of the participants after the randomization was performed provided.

Another randomized control trail focusing on the effects of propofol on PAED scores within a pediatric population undergoing an adenotonsillectomy procedure was conducted by Lee et al. (2010) (Appendix F-1d, 2d). This study included 88 patients ranging in age from 3- 8 years old. All participants had an ASA score of 1. Patients were randomly assigned to either receive propofol or to a control group receiving saline. Patients received $1 \mathrm{mg} / \mathrm{kg}$ of intravenous thiopental pre-operatively. Anesthesia was then induced with an additional $5 \mathrm{mg} / \mathrm{kg}$ of thiopental and $0.5 \mathrm{mg} / \mathrm{kg}$ of atracurium. An orotracheal intubation was performed and general anesthesia was maintained with 
sevoflurane at 2-2.5\% combined with a $50 \%$ nitrous oxide and oxygen mixture. Either 1 $\mathrm{mg} / \mathrm{kg}$ of propofol or $0.1 \mathrm{ml} / \mathrm{kg}$ of saline was administered at the completion of the procedure after the inhalation agents were discontinued. The PAED scores were obtained at five, 15 and 30 minute intervals after arrival to the PACU. The average PAED scores for the propofol group were 12.6 at five minutes, 8.2 at 15 minutes and 5.0 at the thirtyminute recording. PAED scores for the saline group were increased at all three intervals with scores of $13.8,8.0$ and 4.5 respectively. One patient from the trial had a parent present in the PACU. Emergence times averaged 13.7 minutes for the propofol group and 12.2 minutes for the saline group. Average time of discharge from the PACU was 24.2 minutes within the propofol group and 25 minutes for the saline group. Nausea and vomiting were reported in four of the propofol patients and six of those that received saline. No other adverse effects were reported.

Although this study showed a decrease in PAED scores within the propofol group there were significant limitations. The sample size was small and with $\mathrm{P}$ values between 0.655 and 0.815 (Appendix F-3d), the results lacked significance. The painful nature of the procedure made it difficult to determine whether the behaviors exhibited by the patient were related to post-operative pain or EA.

The study conducted by Lee et al. (Appendix G-4) reported participant selection, randomization and attrition using the CONSORT flow diagram. Although the number of patients within the initial pool of participants was not specified, a total of 13 patients were lost after randomization. Five patients from the propofol group did not receive the intervention related to severe agitation at induction, laryngospasm or an inadequate caudal block. Eight patients from the control groups were eliminated for the same 
reasons. The data obtained from a patient within the propofol group was omitted related to ST depressions during the procedure. A patient from the control group was also not included within the final analysis related to excessive surgical bleeding.

\section{Opthalmic procedures}

The randomized control trial performed by Aouad et al. (2007) (Appendix F-1e, 2e) involved 77 pediatric patients ranging in age from two to six years old. The patients underwent either bilateral strabismus surgery $(n=23)$ or unilateral strabismus surgery $(n$ =18). All the participants had an ASA of 2 or lower. The mean duration of the procedures was 39 minutes. Patients received oral midazolam $(0.5 \mathrm{mg} / \mathrm{kg}) 30$ minutes prior to arrival to the operating room. Mask inhalation induction was performed with sevoflurane and nitrous oxide and an LMA was implemented to maintain the airway. General anesthesia was maintained with $2-3 \%$ sevoflurane along with a $60 \%$ nitrous oxide and $40 \%$ oxygen mixture. Antiemetic medications including paracetamol and dexamethasone were given peri-operatively. At the completion of the procedure and once the inhaled anesthetics were discontinued, the propofol group received $1 \mathrm{mg} / \mathrm{kg}$ of propofol and the control group received an equivalent volume of saline. The PAED scores were obtained upon removal of the LMA and in unspecified time intervals until the patient was deemed calm. The overall mean PAED score for the propofol group was $8.6 \pm 3.9$ compared to that of the saline group $11.5 \pm 4.5$. There were differences among the patients that underwent unilateral versus bilateral procedures. The patients that received propofol had a mean PAED score of $8.3 \pm 2.7$ while undergoing a unilateral procedure, whereas the patients that underwent bilateral procedures had a mean PAED score of $8.9 \pm 4.7$. The saline group also experienced an increase of PAED scores among 
those that underwent a bilateral procedure. Recipients of the saline intervention during a unilateral procedure had a mean PAED score of $10 \pm 4$. Those that underwent a bilateral procedure had an increased mean PAED score of $13.2 \pm 4.5$. Emergence times among the propofol group were slightly increased at $23.4 \pm 5.7$ minutes compared to $19.7 \pm 5$ minutes experienced by the patients administered saline. All patients within this study had parental presence during the post recovery stage. Discharge times from the PACU were not adversely affected by the administration of propofol compared to that of those that received saline. The propofol group was discharged in an average of $34.1 \pm 8.4$ minutes whereas the saline group averaged $34.9 \pm 8.6$ minutes. Parents were present with all participants during the recovery stage and no adverse events were reported.

This study involved a procedure that has a high incidence of EA, making it a very relevant study to include in this systematic review (Appendix F-3e). A decrease in PAED scores was demonstrated within the propofol group with a $\mathrm{P}$ value $=.004$. Although a significant correlation was reported, PAED scoring was more difficult within this patient population. Forty-four patients within the propofol group had a unilateral procedure done, where as the remaining 56 patients had a bilateral procedure performed. There were 58 patients that received unilateral treatment and 42 patients that underwent bilateral procedures within the saline group. One of the items within the PAED scoring system is for the child to make eye contact with the assessor. Due to the nature of this procedure and the location of bandages and protective eye wear, the PAED scores within this study may have been affected.

A CONSORT flow diagram was created to collect data regarding the selection and analysis of the participants (Appendix G-5). The study did not include information 
about the initial pool of participants nor detailed information about the one patient from the control group that was excluded from the final analysis.

Chen et al. (2010) (Appendix F-1f, 2f) conducted a randomized control trial involving 120 pediatric patients undergoing cataract surgery. Laterality of the procedure was not specified. The participants were aged from one to seven years old and all had ASA scores of 2 or less. Average surgical time was 32 minutes. No medications were administered preoperatively and anesthesia was induced with sevoflurane and oxygen through mask inhalation. Remifentanil $(0.15 \mathrm{mcg} / \mathrm{kg} / \mathrm{min})$ was administered intravenously, along with a one-time dose of atropine $(0.01 \mathrm{mg} / \mathrm{kg})$. An LMA was placed and general anesthesia was maintained with $1.5-2 \%$ sevoflurane and oxygen. The remifentanil infusion was titrated to maintain ventilation $(.05-0.25 \mathrm{mcg} / \mathrm{kg} / \mathrm{min})$. Patients were randomly assigned to one of three groups $(n=40)$. Once the procedure was finished, children in the propofol group were administered $1 \mathrm{mg} / \mathrm{kg}$ of propofol combined with $0.5 \mathrm{mcg} / \mathrm{kg}$ of fentanyl. The ketamine group received $0.5 \mathrm{mcg} / \mathrm{kg}$ of ketamine combined with $0.5 \mathrm{mcg} / \mathrm{kg}$ of fentanyl, and the midazolam group received $0.05 \mathrm{mg} / \mathrm{kg}$ midazolam combined with $0.5 \mathrm{mcg} / \mathrm{kg}$ of fentanyl. The PAED scores were recorded upon arrival at PACU and at five, 10, 15 and 30-minute intervals. The number of patients with PAED scores higher than 10 and 15 were also recorded. The mean PAED score of the propofol group was 6, with a score range of 3 to 15 . A total of eight patients had PAED scores equal or higher than 10, and an additional three patients scored a 15 or higher. The ketamine group had a mean PAED score of 9 with a scores ranging from 310. Eighteen patients had a PAED score equal or greater than 10 , and ten patients scored higher than 15. Patients in the midazolam group had a mean PAED score of 5 with a 
range of 2-15. Six patients had PAED scores greater than or equal to 10 , and only one patient had a score greater than 15. Average emergence time for those patients in the propofol group was $17.0 \pm 2.1$ minutes. The midazolam and ketamine groups had average emergence times of $21.2 \pm 3.5$ minutes and $19.4 \pm 5.2$ minutes respectively. Average time to discharge for the propofol group was $27.3 \pm 4.9$ minutes, where as the midazolam group experienced an average of $29.3 \pm 6.2$ minutes and the ketamine group averaged $30.4 \pm 3.3$ minutes. Parental presence during recovery was not specified. The ketamine group had two patients with hallucinations and nightmares. No other adverse reactions were reported.

The study conducted by Chen et al. (Appendix F-3f) had also demonstrated a significant decrease in PAED scores within the propofol group with a $\mathrm{P}$ value of $<0.05$. Limitations of this study included the lack of a placebo group as well as fentanyl being administered as part the interventions. As with the previous study involving ocular procedures, visual acuity is affected and may make PAED scoring difficult in the post operative period.

A CONSORT flow diagram was created for this study to collect the data reported concerning the sample selection, allocation and attrition rates (Appendix G-6). The study did not provide information regarding the initial patient pool from which their participants were selected. There were no participants lost to follow up or analysis after the initial selection and randomization into treatment groups.

\section{Inguinal hernia procedures}

Kim et al. (2012) (Appendix F-1g, 2g) compared the use of fentanyl and propofol for the prevention of EA in pediatric patients undergoing inguinal hernia repair. All 
patients were an ASA 2 or below. A total of 205 patients ranging in age from one to six years old were randomly assigned to three groups. A control group was administered an unspecified amount of saline at the completion of surgery. Patients within the interventional groups received wither $1 \mathrm{mg} / \mathrm{kg}$ of propofol or $1 \mathrm{mcg} / \mathrm{kg}$ of fentanyl. All patients received a caudal block with $0.5 \%$ bupivacaine $(1.2 \mathrm{ml} / \mathrm{kg})$ after a mask inhalation induction with $8 \%$ sevoflurane and placement of an LMA. Anesthesia was maintained with sevoflurane $2-2.5 \%$ with a $50 \%$ oxygen flow. No pre-medications were administered. PAED scores were obtained upon the arrival to PACU and at five minute intervals for the first 30 minutes. The average score was then reported for each group. The propofol group had a mean PAED score of 4.3, compared to 9.0 and 4.9 of the saline and fentanyl group respectively. The average emergence time of the propofol group was 27.7 minutes compared to the 17.6 minutes of the saline group and 17.6 minutes of the fentanyl group. Discharge from PACU took an average of 37.1 minutes for the propofol group and 33.4 minutes for the saline group. The fentanyl group was the most delayed with an average time of 40.4 minutes. There were no parents present in the PACU during this trial. Airway obstruction was noted in two patients within the propofol group and four that received fentanyl. Laryngospasm was reported in one patient in both the propofol and fentanyl groups. Nausea and vomiting was present in four of the propofol patients, two of the saline participants and 17 of those patients that received fentanyl. No other adverse reactions were reported.

This study had the advantage of a large sample size and reported a significant correlation between the administration of propofol and decreased PAED scores with a P value of $<0.001$ (Appendix F-3g). The use of a caudal block deemed this a relatively 
painless procedure, eliminating the chance of post operative pain being assessed as EA. Limitations of this study included the elimination of patients that showed anxiety preoperatively which is considered a contributing factor to EA. Inguinal hernia repair has a low incidence of EA making the results of the study less generalizable to other pediatric surgical procedures.

The CONSORT flow diagram was used in the study to report data related to sample selection, allocation and attrition (Appendix G-7). Of the original 265 patients assessed for the study, 43 were excluded related either not meeting inclusion criteria or declining to participate. Of the patients that were selected and randomized into interventional groups, 17 were not included in the study due to either extreme agitation during induction, laryngospasm or inadequate caudal blocks.

\section{Cross Study Analysis}

The randomized control trials used for this systematic review were analyzed across studies utilizing the data collection sheet previously depicted in Table 2. This tool was used to record and analyze the PAED scores, emergence times, discharge times and adverse effects amongst the propofol and control groups for each review (Appendix $H$ ).

All the randomized control trials included within this systematic review reported a decrease in PAED scores for children who received propofol prior to emergence after receiving a sevoflurane based general anesthetic (Appendix $\mathrm{H}-1,2,3,4,5,6,7$ ). The most profound decreases were found within the studies involving non-painful procedures such as outpatient MRI procedures. The study conducted by Abu-Shahwan (Appendix $\mathrm{H}-1)$ reported a peak PAED score of seven $(\mathrm{P} \leq 0.05)$ within the propofol group compared to that of $13(\mathrm{P} \leq 0.05)$ of the control group. Costi (Appendix H-2) reported a 
peak PAED score of six $(\mathrm{P} \leq 0.001)$ within the propofol group compared to a peak score of 10 within the control group.

The seven studies also did not report a significant change in either the average emergence times nor the time of discharge from the post recovery area between the propofol and control groups (Appendix H). Five studies reported increased emergence times for the propofol groups ranging from 1.5 to 10 minutes (Appendix $H-1,2,4,5,7$ ). One study reported a decrease in emergence time of 1.6 minutes (Appendix H-3), whereas the remaining study did not contain a control group for which a comparison could be made (Appendix H-6). Discharge times were increased from between 0.6 to 3.7 minutes in two of the studies included within this review (Appendix H-3, 7). Four trials reported an overall decrease in discharge times ranging from 0.8 to 4 minutes (Appendix $\mathrm{H}-1,2,4,5)$. One trial did not contain a control group for which a comparison could be made (Appendix H-6).

There were few adverse effects reported within the propofol groups of the studies included with this systematic review. Three studies reported no adverse effects for both the control and interventional groups (Appendix H-1, 5, 6). Nausea and vomiting was reported in three studies (Appendix H-3, 4, 7) and was the most common adverse event within the propofol groups. Laryngospasm was the second most common adverse effect and was reported within two of the studies for the children that received propofol (Appendix H-2, 7).

Next, summary and conclusions section will be presented. 


\section{Summary and Conclusions}

Emergence agitation among pediatric patients undergoing general anesthesia is a disruptive phenomenon. Children that experience EA are at a greater risk of self-injury, interruption of medical treatment, increased stress upon caregivers and longer lengths of stays (Vlajkovic \& Sindjelic, 2007). Sevoflurane has been associated with an increased rate of EA in as high as $80 \%$ of children undergoing procedures under general anesthesia (Kim et al., 2011). A literature review was conducted and found that although many systematic reviews and meta-analyses existed, there was a lack of a single consistent method of detecting and quantifying EA. The PAED scale is a five-item tool designed to quantify emergence agitation in the pediatric patient (Sikich \& Lerman, 2004). This scale was developed to provide a consistent and reliable tool in which EA can be measured. It is for this reason the author chose studies that incorporated this tool for the purpose of evaluating EA in their patient populations. The purpose of this paper was to conduct a systematic review to determine if the administration of a sub-hypnotic dose of propofol would decrease the incidence and severity of the emergence agitation based upon PAED scores in children undergoing general anesthesia with sevoflurane.

A literature review was conducted utilizing inclusion and exclusion criteria created by the author. The PRISMA flowchart (Figure 2) was used to assist in the organization and collection of data regarding the literature search. A total of eight articles were selected, seven of which were randomized control trials. The randomized control trials were subject to further critique using the CONSORT checklist (Appendix B) in order to assure the strength and significance of the studies included within this systematic review. Data were collected from the articles and recorded within tables 
created by the author (Appendix C). Information that was obtained from each study included title, author, publication date, number of patients in trial, ages of participants, gender, ASA score, procedure performed, duration of procedure, allocation of participants to control and propofol groups, dose of propofol, intervention doses, timing of administration, other medications given, PAED scores and times, parental presence, emergence times, discharge times, airway interventions and any adverse events reported (Appendix F-1,2). Strengths and weaknesses from each study were recorded within another table created by the author of this review using the criteria listed within the CONSORT checklist (Appendix F-3). The CONSORT flow diagram, which focuses on the sample size, randomization and attrition rates of participants, was completed for each randomized control trial (Appendix $G-1,2,3,4,5,6,7$ ). Analysis across the studies was performed utilizing the chart located in Appendix H. This chart recorded the PAED scores, emergence times, discharge times and adverse effects of both the propofol and control groups for all seven randomized control trials.

All seven of the randomized control trials used for this review reported a decrease in PAED scores in patients that received at least $1 \mathrm{mg} / \mathrm{kg}$ of intravenous propofol prior to emergence (Appendix H-1, 2, 3, 4, 5, 6, 7). The most profound decreases in PAED scores were found within the studies that did not involve painful procedures such as undergoing an MRI as an outpatient (Appendix H-1, 2). The patients in the Costi et al. study (Appendix H-2) received a higher dose of propofol than the other six studies; $3 \mathrm{mg} / \mathrm{kg}$ versus $1 \mathrm{mg} / \mathrm{kg}$. This increased dose may have affected the PAED scores. AbuShahwan (Appendix F-2a) also looked at the effects of propofol on PAED scores among pediatric patients undergoing MRI and utilized the sub-hypnotic dose of propofol (1 
$\mathrm{mg} / \mathrm{kg}$ ). Pain can affect the ability to distinguish EA from delirious behavior associated with noxious stimuli, which can have a significant affect on the ability to accurately assess PAED scores. Examination of the PAED scores of patients undergoing painless procedures helped to validate the effect of propofol on EA.

Procedures that are associated with more intraoperative and postoperative pain also showed a decrease in PAED scores when a sub-hypnotic dose of propofol was administered prior to emergence. Pediatric patients undergoing adenotonsillectomy procedures were studied by Ali (Appendix H-3) and Lee (Appendix H-4). The study conducted by Lee reported decreased initial average PAED scores within the propofol group (12.6) as compared to that of the saline group (13.8). Decreased PAED scores were also recorded in the Ali study with the propofol group having an initial average PAED score of 11.6 compared to that of the saline group, which averaged a score of 13.7 . A third interventional group received dexmedetomidine and had an even lower reported average PAED score of 9.8. Adenotonsillectomies are a more painful procedure than that of an MRI and a patient's response to pain may be misread as EA. It may be for these reasons that the overall PAED scores are higher than those in the studies involving the MRI and the differences between the saline group and propofol group less significant. The use of precedex provided the lowest severity of EA and could be attributed to its analgesic effects for which propofol lacks.

All seven of the studies did not report a significant increase in either the average emergence times nor the time of discharge from the post recovery area between the propofol and control groups (Appendix H-1, 2, 3, 4, 5, 6, 7). The propofol groups had emergence times between 2 and 6 minutes longer than the control groups in six of the 
studies (Appendix H-1, 2, 4, 5, 7). The study conducted by Kim et al (Appendix H-7) had an emergence time among the propofol group that was 10 minutes longer than the control group. This may have been attributed to the analgesic effects of the caudal block administered prior to the procedure. Discharge from the post recovery area was also not greatly affected by the administration of propofol prior to emergence. In two of the studies the discharge time increased by 0.6 to 4 minutes (Appendix H-3, 7). Four studies (Appendix H-1, 2, 4, 5) showed a decrease in discharge times within the propofol group when compared to those patients within the control group. The one study that lacked a control group had a discharge of time of $27.3 \pm 4.9$ minutes (Appendix H-6).

Adverse effects were reported in four of the seven randomized control trials (Appendix H-2, 3, 4, 7). Laryngospasms, airway obstruction, and post-operative nausea and vomiting (PONV) were the most commonly reported events. The patients with reported episodes of PONV within the propofol groups (Appendix H-3, 4, 7) were within studies that included procedures with an existing higher incidence of PONV such as strabismus surgery and adenotonsillectomy procedures (Appendix H-4, 5).

Although diversity amongst the procedures performed provided stronger evidence for this systematic review, the differences amongst the timing and recording of PAED scores potentially weakened the conclusions that can be drawn from the data synthesis. The PAED scores were recorded at various time intervals, and in the case of the study conducted by Aouad (Appendix F-2e) time intervals were not accurately described. Studies differed on their reporting of PAED scores by the means of average scores, peak scores, ranges and number of patients that achieved scores higher than 10 or 15 . A 
consistent scoring timeline and recording algorithm would have provided stronger evidence of the effect of propofol on the reduction of PAED scores.

There were limitations of this systematic review process. Though the studies included in this review met the inclusion criteria, which were identified as reasonable, the inclusion of seven randomized control trials with relatively small sample sizes overall may lessen the generalizability to the pediatric surgical population at large. This review may have benefitted from selecting trials of subjects undergoing identical surgical procedures. Variables such as pain and body systems affected would not have been able to potentially affect the PAED scores. Non-painful procedures, such as outpatient MRI studies and inguinal hernia repairs performed under a caudal block (Appendix F-2a, 2b, $2 \mathrm{~g}$ ) were stronger studies related to eliminating the risk of interpreting the patients' response to pain as EA. In contrast, adenotonsillectomy procedures (Appendix F-2c, 2d), which are associated with more discomfort post-operatively, had higher PAED scores than that of the MRI studies (Appendix F-2a, 2b, 2c, 2d). These higher PAED scores may not have been a direct reflection of EA, but rather of the misinterpretation of the child's response to pain. Studies that included patients undergoing ophthalmic procedures (Appendix F-2e, 2f) were at risk for obtaining weakened results related to the inability to assess accurate PAED scores. One of the items on the PAED scoring system included making eye contact with the assessor (Figure 1). Due to decreased visual acuity related to the procedure itself and subsequent bandages and protective eye wear required post operatively, the inability to assess this portion of the PAED scoring system may have affected the strength of the results. 
Despite these limitations, this systematic review provides sufficient evidence to implicate propofol as an effective means to reduce EA in the pediatric patient population. Recommendations and implications for advanced nursing practice will be discussed in the next section. 


\section{Recommendations and Implications for Advanced Nursing Practice}

Certified Registered Nurse Anesthetists (CRNAs) are Advanced Practice

Registered Nurses (APRNs) that rely on evidence-based research daily. Systematic reviews provide the tools and evidence required in order to provide safe anesthesia. CRNAs are responsible for the peri-operative care of the pediatric patient. CRNAs provide safe and uneventful emergency and recovery of the pediatric patient until the intraoperative report is conveyed to the Post Anesthesia Recovery Unit (PACU) nurse. Emergence agitation during emergence with the use of sevoflurane in the pediatric population makes waking increasingly unpredictable for the CRNA and operating room staff.

The administration of anesthesia is a combination of both a science and an art. Competence is achieved through education, clinical practice and developing a safe and effective technique of administering personalized and appropriate anesthesia. Continuing education is crucial to both the education of the anesthesia provider and the safety of their patients. Systematic reviews such as the one created by this author are intended to provide up to date information regarding the latest, safest and most effective methods of providing anesthesia across the lifespan. This information can be used not only to improve the practice of existing practitioners, but also become incorporated in the curriculum of institutions training future CRNAs.

The use of propofol prior to emergence has been shown to decrease the PAED scores in children undergoing a variety of procedures in this systematic review. Not only have the PAED scores been lowered, but also the overall emergence times and discharge from hospital times were minimally effected. Many practitioners are hesitant in 
administering propofol prior to emergence and extubation related to an increased risk of adverse effects such as airway obstruction and subsequent laryngospasm. As the data within Appendix H shows, there were minimal events within the propofol group and no significant differences between those receiving either a control or alternate intervention. Propofol in sub-hypnotic doses is considered an anti-emetic within itself and can actually decrease the incidence of PONV (Miller, 2015).

Emergence agitation episodes can not only cause stress and increase the potential for injury for the patient, but it can also increase the stress and decrease the satisfaction of the caregiver/parent. In the ever-changing field of health care, there has been a focus on patient satisfaction and most recently this has affected the reimbursement protocols for many Medicare and Medicaid patients. If patients are dissatisfied with their care, including pain control and overall experience, the hospital may not be paid the full reimbursement allocated for the procedure. Although pediatric patients often do not receive care from either the Medicare or Medicaid agencies, caution must be exercised if the trend continues in the future, other insurance plans and healthcare programs may follow suit and a wider population of patients may be affected. Creation of policies that direct the CRNA to provide prophylactic measures to decrease the incidence and severity of EA may become commonplace as this emphasis on patient satisfaction continues.

This systematic review may also be the backboard to many future research endeavors. Propofol was shown to decrease the incidence and severity of EA in the pediatric population, but as the study conducted by Ali (Appendix F-2c) reported, dexmedetomidine had an even greater effect on lowering PAED scores. Future studies may be performed comparing dexmedetomidine and propofol and their effects on EA. 
There are many other surgical and procedural factors that may be examined in relation to their effects on EA as a result of this systematic review. Numerous variables could be further researched including surgical duration, patient gender and parental presence to see if they have an overall effect on PAED scores. These studies would be essential in developing even safer and more effective anesthetic protocols in the pediatric surgical population. 


\section{References}

Abu-Shahwan, I. (2008). Effect of propofol on emergence behavior in children after sevoflurane general anesthesia. Pediatric Anesthesia, 18, 55-59. doi:10.1111/j.1460-9592.2007.02376.x

Ali, M. A., \& Abdellatif, A. A. (2013). Prevention of sevoflurane related emergence agitation in children undergoing adenotonsillectomy: A comparison of dexmedetomidine and propofol. Saudi Journal of Anaesthesia, 7(3), 296-300. doi:10.4103/1658-354X.115363

Aouad, M. T., Yazbeck-Karam, V. G., Nasr, V. G., El-Khatib, M. F., Kanazi, G. E., \& Bleik, J. H. (2007). A single dose of propofol at the end of surgery for the prevention of emergence agitation in children undergoing strabismus surgery during sevoflurane anesthesia. Anesthesiology, 107, 733-738. http://dx.doi.org/doi:10.1097/01.anes.0000287009.46896.a

Chen, J., Li, W., Hu, X., \& Wang, D. (2010). Emergence agitation after cataract surgery in children: a comparison of midazolam, propofol and ketamine. Pediatric Anesthesia, 20, 873-879. doi:10.1111/j.1460-9592.2010.03375.x

CONSORT (2010). www.consort-statement.org

Costi, D., Ellwood, J., Wallace, A., Ahmed, S., Waring, L., \& Cyna, A. (2015). Transition to propofol after sevoflurane anesthesia to prevent emergence agitation: a randomized controlled trial. Paediatric Anaesthesia, 5(25), 517-523. doi:10.1111/pan.12617

Key, K. L., Rich, C., DeCristofaro, C., \& Collins, S. (2010). Use of propofol and emergence agitation in children: A literature review. AANA Journal, 70(6), 468473. Retrieved from 
https://www.aana.com/newsandjournal/Documents/useofpropofol_1210_p468473.pdf

Kim, M., Moon, B., Kim, H., \& Lee, J. (2012). Comparison of propofol and fentanyl administered at the end of anaesthesia for prevention of emergence agitation after sevoflurane anaesthesia in children. British Journal of Anaesthesia, 2(110), 27480. doi: 10.1093/bja/aes382

Kim, Y. H., Yoon, S. Z., Lim, H. J., \& Yoon, S. M. (2011). Prophylactic use of midazolam or propofol at the end of surgery may reduce the incidence of emergence agitation after sevoflurane anaesthesia. Anaesthesia and Intensive Care, 39(5), 904-908. Retrieved from http://0web.b.ebscohost.com.helin.uri.edu/ehost/pdfviewer/pdfviewer?vid=2\&sid=a5547 d45-bfbd-48cc-a8dd-15e81302025e\%40sessionmgr110\&hid=125

Lee, C. J., Lee, S. E., Oh, M. K., Shin, C. M., Kim, Y. J., Choe, Y. K., ... Lim, S. H. (2010). The effect of propofol on emergence agitation in children receiving sevoflurane for adenotonsillectomy. Korean Journal of Anesthesiology, 2(52), 7581. doi:10.4097/kjae.2010.59.2.75

Messieha, Z. (2013). Prevention of sevoflurane delirium and agitation with propofol. Anesthesia Progress, 60(2), 67-71. doi:10.2344/0003-3006-60.3.67

Miller, R. D., Cohen, N. H., Eriksson, L. I., Fleisher, L. A., Wiener-Kronish, J. P., \& Young, W. L. (Eds.). (2015). Miller's Anesthesia (8th ed.). Philadelphia, PA: Elsevier Saunders. 
Moher, D., Liberati, A., Tetzlaff, J., \& Altman, D. (2009). Preferred reporting items for systematic reviews and meta-analyses: The PRISMA statement. PLoS Medicine, 6(7), 1-6. doi:10.1371/journal.pmed.1000097

Nagelhout, J. J., \& Plaus, K. L. (2014). Nurse Anesthesia (5th ed.). St. Louis, Missouri: Elsevier Saunders.

Reduque, L. L., \& Verghese, S. T. (2012). Paediatric emergence delirium. Continuing Education in Anaesthesia, Critical Care \& Pain, 1-3. doi:10.1093/bjaceaccp/mks051

Sikich, N., \& Lerman, J. (2004). Development and psychometric evaluation of the pediatric anesthesia emergence delirium scale. Anesthesiology, 100, 1138-1145. Retrieved from http://anesthesiology.pubs.asahq.org/article.aspx?articleid=1942731

Vlajkovic, G. P., \& Sindjelic, R. P. (2007). Emergence delirium in children: Many questions, few answers. Anesthesia \& Analgesia, 104(1), 84-91. doi:10.1213/01.ane.0000250914.91881.a8 


\section{Appendix A}

\section{PRISMA 2009 Checklist}

\begin{tabular}{|c|c|c|c|}
\hline Section/topic & $\#$ & Checklist item & $\begin{array}{l}\text { Reported } \\
\text { on page \# }\end{array}$ \\
\hline \multicolumn{4}{|l|}{ TITLE } \\
\hline Title & 1 & Identify the report as a systematic review, meta-analysis, or both. & \\
\hline \multicolumn{4}{|l|}{ ABSTRACT } \\
\hline Structured summary & 2 & $\begin{array}{l}\text { Provide a structured summary including, as applicable: background; objectives; data sources; study eligibility criteria, } \\
\text { participants, and interventions; study appraisal and synthesis methods; results; limitations; conclusions and } \\
\text { implications of key findings; systematic review registration number. }\end{array}$ & \\
\hline \multicolumn{4}{|l|}{ INTRODUCTION } \\
\hline Rationale & 3 & Describe the rationale for the review in the context of what is already known. & \\
\hline Objectives & 4 & $\begin{array}{l}\text { Provide an explicit statement of questions being addressed with reference to participants, interventions, comparisons, } \\
\text { outcomes, and study design (PICOS). }\end{array}$ & \\
\hline \multicolumn{4}{|l|}{ METHODS } \\
\hline Protocol and registration & 5 & $\begin{array}{l}\text { Indicate if a review protocol exists, if and where it can be accessed (e.g., Web address), and, if available, provide } \\
\text { registration information including registration number. }\end{array}$ & \\
\hline Eligibility criteria & 6 & $\begin{array}{l}\text { Specify study characteristics (e.g., PICOS, length of follow-up) and report characteristics (e.g., years considered, } \\
\text { language, publication status) used as criteria for eligibility, giving rationale. }\end{array}$ & \\
\hline Information sources & 7 & $\begin{array}{l}\text { Describe all information sources (e.g., databases with dates of coverage, contact with study authors to identify } \\
\text { additional studies) in the search and date last searched. }\end{array}$ & \\
\hline Search & 8 & $\begin{array}{l}\text { Present full electronic search strategy for at least one database, including any limits used, such that it could be } \\
\text { repeated. }\end{array}$ & \\
\hline Study selection & 9 & $\begin{array}{l}\text { State the process for selecting studies (i.e., screening, eligibility, included in systematic review, and, if applicable, } \\
\text { included in the meta-analysis). }\end{array}$ & \\
\hline Data collection process & 10 & $\begin{array}{l}\text { Describe method of data extraction from reports (e.g., piloted forms, independently, in duplicate) and any processes } \\
\text { for obtaining and confirming data from investigators. }\end{array}$ & \\
\hline Data items & 11 & $\begin{array}{l}\text { List and define all variables for which data were sought (e.g., PICOS, funding sources) and any assumptions and } \\
\text { simplifications made. }\end{array}$ & \\
\hline $\begin{array}{l}\text { Risk of bias in individual } \\
\text { studies }\end{array}$ & 12 & $\begin{array}{l}\text { Describe methods used for assessing risk of bias of individual studies (including specification of whether this was } \\
\text { done at the study or outcome level), and how this information is to be used in any data synthesis. }\end{array}$ & \\
\hline Summary measures & 13 & State the principal summary measures (e.g., risk ratio, difference in means). & \\
\hline Synthesis of results & 14 & $\begin{array}{l}\text { Describe the methods of handling data and combining results of studies, if done, including measures of consistency } \\
\left(\mathrm{e} . \mathrm{g.}, \mathrm{I}^{2}\right) \text { for each meta-analysis. }\end{array}$ & \\
\hline
\end{tabular}

\begin{tabular}{|c|c|c|c|}
\hline Section/topic & \# & Checklist item & $\begin{array}{l}\text { Reported } \\
\text { on page \# }\end{array}$ \\
\hline Risk of bias across studies & 15 & $\begin{array}{l}\text { Specify any assessment of risk of bias that may affect the cumulative evidence (e.g., publication bias, selective } \\
\text { reporting within studies). }\end{array}$ & \\
\hline Additional analyses & 16 & $\begin{array}{l}\text { Describe methods of additional analyses (e.g., sensitivity or subgroup analyses, meta-regression), if done, indicating } \\
\text { which were pre-specified. }\end{array}$ & \\
\hline \multicolumn{4}{|l|}{ RESULTS } \\
\hline Study selection & 17 & $\begin{array}{l}\text { Give numbers of studies screened, assessed for eligibility, and included in the review, with reasons for exclusions at } \\
\text { each stage, ideally with a flow diagram. }\end{array}$ & \\
\hline Study characteristics & 18 & $\begin{array}{l}\text { For each study, present characteristics for which data were extracted (e.g., study size, PICOS, follow-up period) and } \\
\text { provide the citations. }\end{array}$ & \\
\hline Risk of bias within studies & 19 & Present data on risk of bias of each study and, if available, any outcome level assessment (see item 12). & \\
\hline Results of individual studies & 20 & $\begin{array}{l}\text { For all outcomes considered (benefits or harms), present, for each study: (a) simple summary data for each } \\
\text { intervention group (b) effect estimates and confidence intervals, ideally with a forest plot. }\end{array}$ & \\
\hline Synthesis of results & 21 & Present results of each meta-analysis done, including confidence intervals and measures of consistency. & \\
\hline Risk of bias across studies & 22 & Present results of any assessment of risk of bias across studies (see Item 15). & \\
\hline Additional analysis & 23 & Give results of additional analyses, if done (e.g., sensitivity or subgroup analyses, meta-regression [see Item 16]). & \\
\hline \multicolumn{4}{|l|}{ DISCUSSION } \\
\hline Summary of evidence & 24 & $\begin{array}{l}\text { Summarize the main findings including the strength of evidence for each main outcome; consider their relevance to } \\
\text { key groups (e.g., healthcare providers, users, and policy makers). }\end{array}$ & \\
\hline Limitations & 25 & $\begin{array}{l}\text { Discuss limitations at study and outcome level (e.g., risk of bias), and at review-level (e.g., incomplete retrieval of } \\
\text { identified research, reporting bias). }\end{array}$ & \\
\hline Conclusions & 26 & Provide a general interpretation of the results in the context of other evidence, and implications for future research. & \\
\hline \multicolumn{4}{|l|}{ FUNDING } \\
\hline Funding & 27 & $\begin{array}{l}\text { Describe sources of funding for the systematic review and other support (e.g., supply of data); role of funders for the } \\
\text { systematic review. }\end{array}$ & \\
\hline
\end{tabular}

(Moher et al., 2009) 


\section{Appendix B}

\begin{tabular}{|c|c|c|c|}
\hline Section/Topic & $\begin{array}{c}\text { Item } \\
\text { No }\end{array}$ & Checklist item & $\begin{array}{l}\text { Reported } \\
\text { on page No }\end{array}$ \\
\hline \multicolumn{4}{|l|}{ Title and abstract } \\
\hline & $1 \mathrm{a}$ & Identification as a randomised trial in the title & \\
\hline & $1 \mathrm{~b}$ & Structured summary of trial design, methods, results, and conclusions (for specific guidance see CONSORT for abstracts) & \\
\hline \multicolumn{4}{|l|}{ Introduction } \\
\hline \multirow{2}{*}{$\begin{array}{l}\text { Background and } \\
\text { objectives }\end{array}$} & $2 a$ & Scientific background and explanation of rationale & \\
\hline & $2 \mathrm{~b}$ & Specific objectives or hypotheses & \\
\hline \multicolumn{4}{|l|}{ Methods } \\
\hline \multirow{2}{*}{ Trial design } & за & Description of trial design (such as parallel, factorial) including allocation ratio & \\
\hline & 3b & Important changes to methods after trial commencement (such as eligibility criteria), with reasons & \\
\hline \multirow[t]{2}{*}{ Participants } & $4 a$ & Eligibility criteria for participants & \\
\hline & $4 \mathrm{~b}$ & Settings and locations where the data were collected & \\
\hline Interventions & 5 & $\begin{array}{l}\text { The interventions for each group with sufficient details to allow replication, including how and when they were } \\
\text { actually administered }\end{array}$ & \\
\hline \multirow[t]{2}{*}{ Outcomes } & $6 a$ & $\begin{array}{l}\text { Completely defined pre-specified primary and secondary outcome measures, including how and when they } \\
\text { were assessed }\end{array}$ & \\
\hline & $6 b$ & Any changes to trial outcomes after the trial commenced, with reasons & \\
\hline \multirow[t]{2}{*}{ Sample size } & $7 a$ & How sample size was determined & \\
\hline & $7 \mathrm{~b}$ & When applicable, explanation of any interim analyses and stopping guidelines & \\
\hline \multicolumn{4}{|l|}{ Randomisation: } \\
\hline \multirow{2}{*}{$\begin{array}{l}\text { Sequence } \\
\text { generation }\end{array}$} & $8 \mathrm{a}$ & Method used to generate the random allocation sequence & \\
\hline & $8 \mathrm{~b}$ & Type of randomisation; details of any restriction (such as blocking and block size) & \\
\hline \multicolumn{2}{|l|}{$\begin{array}{l}\text { Allocation } \\
\text { concealment } \\
\text { mechanism }\end{array}$} & $\begin{array}{l}\text { Mechanism used to implement the random allocation sequence (such as sequentially numbered containers), } \\
\text { describing any steps taken to conceal the sequence until interventions were assigned }\end{array}$ & \\
\hline Implementation & 10 & $\begin{array}{l}\text { Who generated the random allocation sequence, who enrolled participants, and who assigned participants to } \\
\text { interventions }\end{array}$ & \\
\hline Blinding & $11 \mathrm{a}$ & If done, who was blinded after assignment to interventions (for example, participants, care providers, those & \\
\hline \multirow[t]{3}{*}{ CONSORT 2010 checklist } & & & Page 1 \\
\hline & & assessing outcomes) and how & \\
\hline & $11 \mathrm{~b}$ & If relevant, description of the similarity of interventions & \\
\hline \multirow[t]{2}{*}{ Statistical methods } & $12 a$ & Statistical methods used to compare groups for primary and secondary outcomes & \\
\hline & $12 b$ & Methods for additional analyses, such as subgroup analyses and adjusted analyses & \\
\hline \multicolumn{4}{|l|}{ Results } \\
\hline \multirow{2}{*}{$\begin{array}{l}\text { Participant flow (a } \\
\text { diagram is strongly } \\
\text { recommended) }\end{array}$} & $13 a$ & $\begin{array}{l}\text { For each group, the numbers of participants who were randomly assigned, received intended treatment, and } \\
\text { were analysed for the primary outcome }\end{array}$ & \\
\hline & $13 \mathrm{~b}$ & For each group, losses and exclusions after randomisation, together with reasons & \\
\hline \multirow[t]{2}{*}{ Recruitment } & $14 a$ & Dates defining the periods of recruitment and follow-up & \\
\hline & $14 \mathrm{~b}$ & Why the trial ended or was stopped & \\
\hline Baseline data & 15 & A table showing baseline demographic and clinical characteristics for each group & \\
\hline Numbers analysed & 16 & $\begin{array}{l}\text { For each group, number of participants (denominator) included in each analysis and whether the analysis was } \\
\text { by original assigned groups }\end{array}$ & \\
\hline \multirow[t]{2}{*}{$\begin{array}{l}\text { Outcomes and } \\
\text { estimation }\end{array}$} & $17 a$ & $\begin{array}{l}\text { For each primary and secondary outcome, results for each group, and the estimated effect size and its } \\
\text { precision (such as } 95 \% \text { confidence interval) }\end{array}$ & \\
\hline & $17 \mathrm{~b}$ & For binary outcomes, presentation of both absolute and relative effect sizes is recommended & \\
\hline Ancillary analyses & 18 & $\begin{array}{l}\text { Results of any other analyses performed, including subgroup analyses and adjusted analyses, distinguishing } \\
\text { pre-specified from exploratory }\end{array}$ & \\
\hline Harms & 19 & All important harms or unintended effects in each group (tor specific guidance see CONSORT for harms) & \\
\hline \multicolumn{4}{|l|}{ Discussion } \\
\hline Limitations & 20 & Trial limitations, addressing sources of potential bias, imprecision, and, if relevant, multiplicity of analyses & \\
\hline \multirow{2}{*}{$\begin{array}{l}\text { Generalisability } \\
\text { Interpretation }\end{array}$} & 21 & Generalisability (external validity, applicability) of the trial findings & \\
\hline & 22 & Interpretation consistent with results, balancing benefits and harms, and considering other relevant evidence & \\
\hline \multicolumn{4}{|l|}{ Other information } \\
\hline Registration & 23 & Registration number and name of trial registry & \\
\hline Protocol & 24 & Where the full trial protocol can be accessed, if available & \\
\hline Funding & 25 & Sources of funding and other support (such as supply of drugs), role of funders & \\
\hline
\end{tabular}

(CONSORT, 2010) 


\section{Appendix C}

\section{Data Collection Sheet \#2}

\begin{tabular}{|l|l|l|l|l|l|l|l|l|l|l|l|}
\hline $\begin{array}{l}\text { Author, } \\
\text { Year }\end{array}$ & $\begin{array}{l}\text { Propofol } \\
\text { Dose }\end{array}$ & $\begin{array}{l}\text { Intervention } \\
\text { Doses }\end{array}$ & $\begin{array}{l}\text { Time of } \\
\text { Intervention }\end{array}$ & $\begin{array}{l}\text { Anesthestics, } \\
\text { Analgesia \& } \\
\text { other meds }\end{array}$ & $\begin{array}{l}\text { PAED } \\
\text { Propofol } \\
\text { Group }\end{array}$ & $\begin{array}{l}\text { PAED } \\
\text { Interventional/ } \\
\text { Control Group }\end{array}$ & $\begin{array}{l}\text { PAED } \\
\text { scoring } \\
\text { \& } \\
\text { timing }\end{array}$ & $\begin{array}{l}\text { Parental } \\
\text { presence }\end{array}$ & $\begin{array}{l}\text { Emergence } \\
\text { time }\end{array}$ & $\begin{array}{l}\text { Discharge } \\
\text { Time }\end{array}$ & \begin{tabular}{l} 
Airway \\
Adverse \\
Effects \\
\hline
\end{tabular} \\
\hline & & & & & & & & & & & \\
\hline & & & & & & & & & & & \\
\hline
\end{tabular}




\section{Appendix D}

Randomized Control Trial Appraisal Chart

\begin{tabular}{|c|c|c|c|c|c|c|c|c|c|}
\hline Author, Year & Study Type & Consent/Funding & $\begin{array}{l}\text { Inclusion } \\
\text { Criteria }\end{array}$ & $\begin{array}{l}\text { Exclusion } \\
\text { Criteria }\end{array}$ & Randomization & Attrition & Blinding & Strengths & Limitations \\
\hline & & & & & & & & & \\
\hline & & & & & & & & & \\
\hline & & & & & & & & & \\
\hline & & & & & & & & & \\
\hline & & & & & & & & & \\
\hline & & & & & & & & & \\
\hline
\end{tabular}




\section{Appendix E}

\section{PRISMA FLOW DIAGRAM}
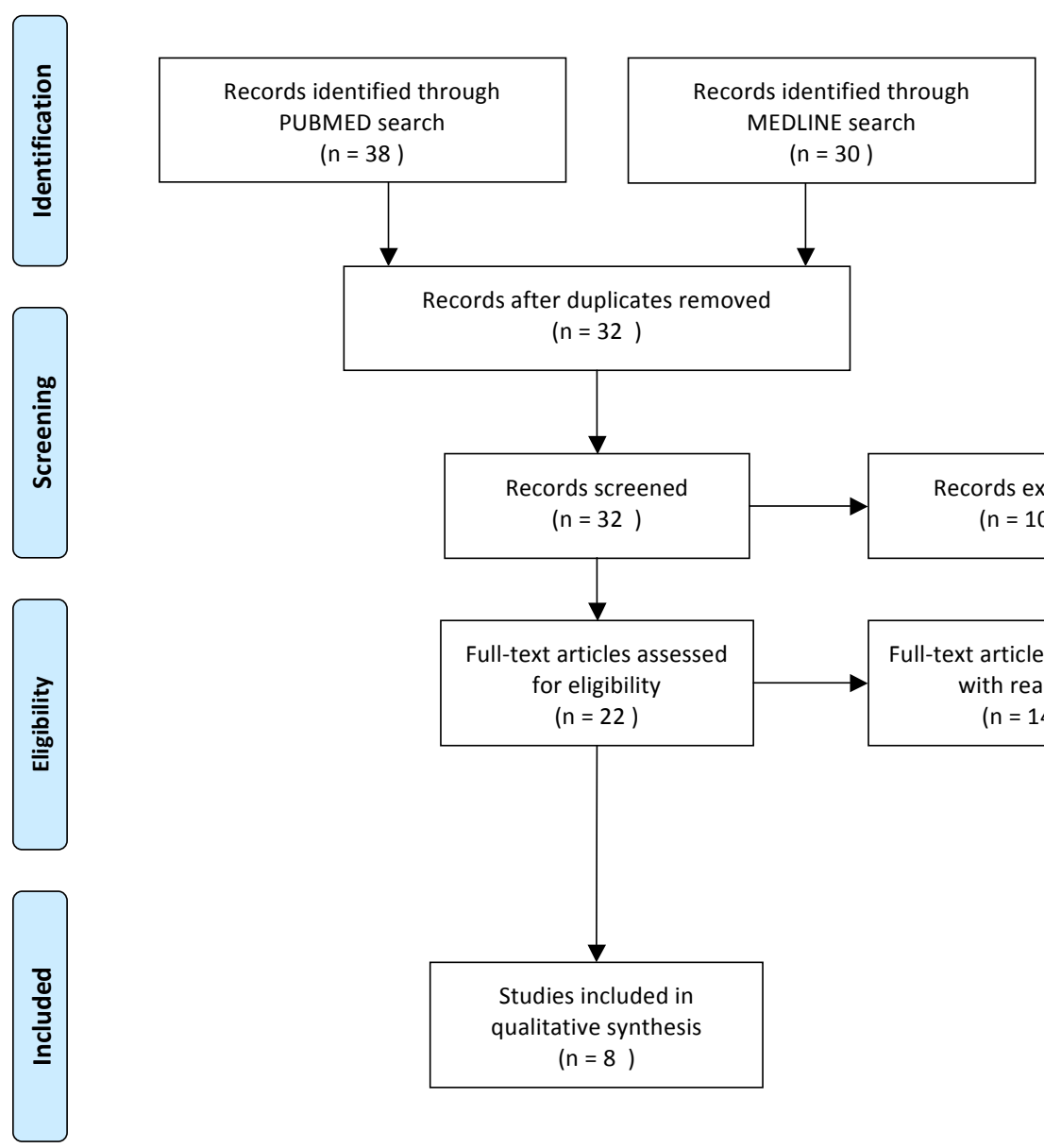

Records after duplicates removed $(n=32)$

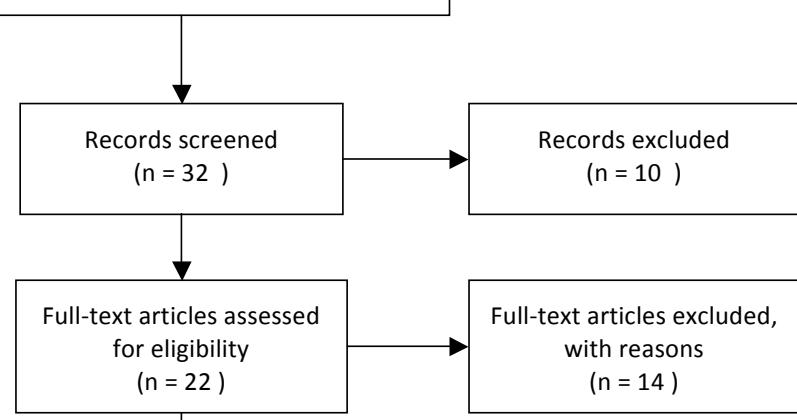

(Moher et al.

Studies included in qualitative synthesis $(n=8)$ 


\section{Appendix F-1}

\section{Data Collection Sheet \#1}

\begin{tabular}{|c|c|c|c|c|c|c|c|c|c|}
\hline & Author, Year & $\begin{array}{l}\text { \# Patients } \\
\text { in Trial }\end{array}$ & Ages (yr) & $\mathrm{M} / \mathrm{F}$ & ASA & Procedures & $\begin{array}{l}\text { Duration } \\
\text { (min) }\end{array}$ & $\begin{array}{l}\text { Propofol } \\
\text { Group }\end{array}$ & $\begin{array}{l}\text { Interventional } \\
\text { Group }\end{array}$ \\
\hline $\mathrm{a}$ & $\begin{array}{l}\text { Abu-Shahwan, } \\
2008\end{array}$ & 83 & $2-7$ & $42 / 41$ & $>2$ & Outpatient MRI & 73 & $\mathrm{n}=42$ & Saline $=41$ \\
\hline $\mathrm{b}$ & Costi, 2015 & 218 & $1-12$ & $119 / 99$ & $\leq 2$ & Outpatient MRI & 64 & $\mathrm{n}=109$ & No intervention $=109$ \\
\hline $\mathrm{c}$ & Ali, 2013 & 120 & $2-6$ & $69 / 51$ & $<\underline{2}$ & Adenotonsillectomy & 58 & $\mathrm{n}=40$ & $\begin{array}{l}\text { Saline }=40 \\
\text { Precedex }=40\end{array}$ \\
\hline $\mathrm{d}$ & Lee, 2010 & 88 & $3-8$ & $51 / 37$ & $\leq 2$ & Adenotonsillectomy & 43 & $\mathrm{n}=44$ & Saline $=44$ \\
\hline e & Auoad, 2007 & 77 & $2-6$ & $40 / 37$ & $\leq 2$ & Strabismus & 39 & $\begin{array}{l}\mathrm{n}=41 \\
\text { unilateral }=18 \\
\text { bilateral }=23\end{array}$ & $\begin{array}{l}\text { Saline }=36 \\
\text { unilateral }=20 \\
\text { bilateral }=16\end{array}$ \\
\hline $\mathrm{f}$ & Chen, 2010 & 120 & $1-7$ & $49 / 71$ & $\leq 2$ & Cataract & 32 & $\begin{array}{l}\mathrm{n}=40 \\
(\mathrm{w} / \text { fentanyl) }\end{array}$ & $\begin{array}{l}\text { Ket } / \text { Fent }=40 \\
\text { Midaz/Fent }=40\end{array}$ \\
\hline $\mathrm{g}$ & Kim, 2012 & 205 & $1-6$ & $138 / 67$ & $\leq 2$ & Inguinal hernia & 62 & $\mathrm{n}=69$ & $\begin{array}{l}\text { Fentanyl }=66 \\
\text { Saline }=70\end{array}$ \\
\hline
\end{tabular}




\section{Appendix F-2}

Data Collection Sheet \#2

\begin{tabular}{|c|c|c|c|c|c|c|c|c|c|c|c|c|c|}
\hline & $\begin{array}{l}\text { Author, } \\
\text { Year }\end{array}$ & $\begin{array}{l}\text { Propofo } \\
1 \text { Dose }\end{array}$ & $\begin{array}{l}\text { Intervention } \\
\text { Doses }\end{array}$ & $\begin{array}{l}\text { Time of } \\
\text { Intervention }\end{array}$ & $\begin{array}{l}\text { Anesthetics, } \\
\text { Analgesia \& } \\
\text { other meds }\end{array}$ & $\begin{array}{l}\text { PAED } \\
\text { propofol }\end{array}$ & $\begin{array}{l}\text { PAED } \\
\text { intervent }\end{array}$ & $\begin{array}{l}\text { PAED } \\
\text { scoring \& } \\
\text { timing } \\
\end{array}$ & $\begin{array}{l}\text { Parental } \\
\text { Presence }\end{array}$ & $\begin{array}{l}\text { Emerge } \\
\text { Time } \\
(\mathrm{min})\end{array}$ & $\begin{array}{l}\text { D/C } \\
\text { Time }\end{array}$ & Airway & $\begin{array}{l}\text { Adverse } \\
\text { Effects }\end{array}$ \\
\hline $\mathrm{a}$ & $\begin{array}{l}\text { Abu- } \\
\text { Shahwan, } \\
2008\end{array}$ & $1 \mathrm{mg} / \mathrm{kg}$ & $\begin{array}{l}\text { Saline-no } \\
\text { dose } \\
\text { specified }\end{array}$ & $\begin{array}{l}\text { End of } \\
\text { procedure } \\
\text { after d/c of } \\
\text { sevo and } \\
\mathrm{N} 2 \mathrm{O} \text {, before } \\
\text { LMA } \\
\text { removal (no } \\
\text { exact time } \\
\text { specified) }\end{array}$ & $\begin{array}{l}60 \% \text { N20 } \\
2 \% \text { Sevo }\end{array}$ & $7(\mathrm{P}<0.05)$ & $\begin{array}{l}\text { Saline }=13 \\
(\mathrm{P}<0.05\end{array}$ & $\begin{array}{l}\text { awakening, } \\
\text { q } 5 \text { min for } \\
1^{\text {st }} 30 \text { min. } \\
\text { Peak scores } \\
\text { recorded }\end{array}$ & $\begin{array}{l}\text { some } \\
\text { parents } \\
\text { were } \\
\text { present, } \\
\text { no exact } \\
\%\end{array}$ & $\begin{array}{l}\text { Propofo } \\
1=9 \pm \\
3.4 \\
\text { Saline }= \\
7 \pm 2.7 \\
\text { P=ns }\end{array}$ & $\begin{array}{l}\text { Prop }= \\
31.21 \pm \\
6.1 \\
\text { Saline }= \\
33.4 \pm \\
5.8 \\
P=n s\end{array}$ & LMA & none \\
\hline b & Costi & $3 \mathrm{mg} / \mathrm{kg}$ & $\begin{array}{l}\text { no } \\
\text { intervention- } \\
\text { al group }\end{array}$ & $\begin{array}{l}\text { completion of } \\
\text { MRI and d/c } \\
\text { of sevo }\end{array}$ & $\begin{array}{l}\mathrm{N} 2 \mathrm{O}-\text { conc. } \\
\text { not specified } \\
\text { Sevo- conc. } \\
\text { not specified }\end{array}$ & $\begin{array}{l}\text { peak }=6 \\
\text { range = 2- } \\
10 \\
\mathrm{P}<0.001\end{array}$ & $\begin{array}{l}\text { peak }=10 \\
\text { range }=6- \\
13 \\
\mathrm{P}<0.001\end{array}$ & $\begin{array}{l}\text { arrival to } \\
\text { PACU and } \\
5 \text { min } \\
\text { intervals } \\
\text { for } 1^{\text {st }} 30 \\
\text { min. Peak } \\
\text { and range } \\
\text { recorded }\end{array}$ & $\begin{array}{l}\text { not } \\
\text { specified }\end{array}$ & $\begin{array}{l}\text { Prop }= \\
17 \pm 10 \\
\text { Control } \\
9 \pm 10 \\
\\
P<0.001\end{array}$ & $\begin{array}{l}\text { Prop }= \\
95 \pm 38 \\
\text { Control } \\
99 \pm 48 \\
\\
\mathrm{P}<0.001\end{array}$ & LMA & $\begin{array}{l}\text { Laryngo- } \\
\text { spasm } \\
\text { occurred in } \\
3 \text { from } \\
\text { control and } \\
1 \text { in } \\
\text { propofol } \\
\text { groups }\end{array}$ \\
\hline $\mathrm{c}$ & Ali, 2013 & $1 \mathrm{mg} / \mathrm{kg}$ & $\begin{array}{l}\text { Saline } 10 \mathrm{ml} \\
\text { Precedex } 0.3 \\
\mathrm{mcg} / \mathrm{kg}\end{array}$ & $\begin{array}{l}5 \text { min before } \\
\text { end of } \\
\text { surgery }\end{array}$ & $\begin{array}{l}60 \% \text { N2O } \\
2-3 \% \text { Sevo } \\
\text { Midazolam } \\
\text { Paracetamol } \\
\text { Decadron } \\
\text { Rocuronium } \\
\text { Neostigmine } \\
\text { Atropine }\end{array}$ & $\begin{array}{l}\text { T0 }=11.6 \\
\text { T5 }=6.6 \\
\text { T15 }=5.7 \\
\text { T30 }=4.1 \\
>15=3 \\
P<0.05\end{array}$ & $\begin{array}{l}\frac{\text { Saline }}{\text { T0 }=13.7} \\
\text { T5 }=8.4 \\
\text { T15 }=5.7 \\
\text { T30 }=4.2 \\
>15=7 \\
\frac{\text { Precedex }}{\text { T0 }=9.8} \\
\text { T5 }=5.2 \\
\text { T15 }=4.2\end{array}$ & $\begin{array}{l}\text { arrival to } \\
\text { PACU(T0), } \\
5,15,30 \\
\text { min } \\
\text { intervals. } \\
\text { total \# of } \\
\text { pts with } \\
\text { PAED >15 } \\
\text { recorded } \\
\text { for each }\end{array}$ & $\begin{array}{l}100 \% \text { of } \\
\text { patients } \\
\text { with } \\
\text { parents } \\
\text { present }\end{array}$ & $\begin{array}{l}\text { Prop= } \\
12.3 \\
\text { Saline= } \\
10.7 \\
\text { Precede } \\
\mathrm{x} \\
10.9 \\
\mathrm{P}<0.05\end{array}$ & $\begin{array}{l}\text { Prop= } \\
38.5 \\
\text { Saline= } \\
37.9 \\
\text { Precede } \\
x \\
40.1 \\
\\
P<0.05\end{array}$ & ETT & $\begin{array}{l}\text { vomit in } \\
\text { propofol } \\
\text { group (5), } \\
\text { saline (3) } \\
\text { precedex } \\
\text { (4) }\end{array}$ \\
\hline
\end{tabular}




\begin{tabular}{|c|c|c|c|c|c|c|c|c|c|c|c|c|c|}
\hline & & & & & & & $\begin{array}{l}\mathrm{T} 30=3.5 \\
>15=2 \\
\mathrm{P}<0.05\end{array}$ & group & & & & & \\
\hline d & Lee, 2010 & $1 \mathrm{mg} / \mathrm{kg}$ & $\begin{array}{l}\text { Saline } \\
0.1 \mathrm{mg} / \mathrm{kg}\end{array}$ & $\begin{array}{l}\text { completion of } \\
\text { procedure } \\
\text { after } \mathrm{d} / \mathrm{c} \text { of } \\
\text { inhalation } \\
\text { agents }\end{array}$ & $\begin{array}{l}\mathrm{N} 2 \mathrm{O} 50 \% \\
\text { Sevo 2-2.5\% } \\
\text { Thiopental } \\
\text { Atracurium } \\
\text { Ketorolac }\end{array}$ & $\begin{array}{l}\mathrm{T} 5=12.6 \\
\mathrm{~T} 15=8.2 \\
\mathrm{~T} 30=5.0 \\
\mathrm{P}=0.6- \\
0.8\end{array}$ & $\begin{array}{l}\mathrm{T} 5=13.8 \\
\mathrm{~T} 15=8.0 \\
\mathrm{~T} 30=4.5 \\
\mathrm{P}=0.6-0.8\end{array}$ & $\begin{array}{l}5,15 \text { and } \\
30 \text { min } \\
\text { after arrival } \\
\text { to PACU }\end{array}$ & $\begin{array}{l}1 \text { patient } \\
\text { had } \\
\text { parental } \\
\text { presence }\end{array}$ & $\begin{array}{l}\text { prop }= \\
13.7 \\
\text { saline }= \\
12.2\end{array}$ & $\begin{array}{l}\text { prop }= \\
24.2 \\
\text { saline }= \\
25\end{array}$ & ETT & $\begin{array}{l}\text { N/V } \\
\text { prop (4) } \\
\text { saline (6) }\end{array}$ \\
\hline e & $\begin{array}{l}\text { Auoad, } \\
2007\end{array}$ & $1 \mathrm{mg} / \mathrm{kg}$ & $\begin{array}{l}\text { Saline - } \\
\text { equal to } \\
\text { volume of } \\
\text { propofol }\end{array}$ & $\begin{array}{l}\text { completion of } \\
\text { surgical } \\
\text { procedure } \\
\text { after } d / c \text { of } \\
\text { inhalation } \\
\text { agents }\end{array}$ & $\begin{array}{l}60 \% \text { N2O } \\
2-3 \% \text { Sevo } \\
\text { Midazolam } \\
\text { Lidocaine } \\
\text { Paracetamol } \\
\text { Decadron }\end{array}$ & $\begin{array}{l}\text { Overall } \\
\text { mean }= \\
8.6 \pm 3.9 \\
\text { Unilat }= \\
8.3 \pm 2.7 \\
\text { Bilat }= \\
8.9 \pm 4.7 \\
\mathrm{P}=0.004\end{array}$ & $\begin{array}{l}\text { Overall } \\
\text { mean }= \\
11.5 \pm 4.5 \\
\text { Unilat }= \\
10 \pm 4 \\
\text { Bilat }= \\
13.2 \pm 4.5 \\
\mathrm{P}=0.004\end{array}$ & $\begin{array}{l}\text { @LMA } \\
\text { removal } \\
\text { cont. } \\
\text { PAED } \\
\text { recording, } \\
\text { highest } \\
\text { score used }\end{array}$ & $\begin{array}{l}100 \% \\
\text { patient } \\
\text { with } \\
\text { parents } \\
\text { present }\end{array}$ & $\begin{array}{l}\text { Prop }= \\
23.4 \pm \\
5.7 \\
\text { Saline }= \\
19.7 \pm \\
5 \\
\mathrm{P}=0.004\end{array}$ & $\begin{array}{l}\text { Prop= } \\
34.1 \pm \\
8.4 \\
\text { Saline }= \\
34.9 \pm \\
8.6 \\
\mathrm{P}=0.68\end{array}$ & LMA & none \\
\hline $\mathrm{f}$ & $\begin{array}{l}\text { Chen, } \\
2010\end{array}$ & $\begin{array}{l}1 \mathrm{mg} / \mathrm{kg} \\
\mathrm{w} / \\
\text { fentanyl } \\
0.5 \\
\mathrm{mcg} / \mathrm{kg}\end{array}$ & $\begin{array}{l}\text { midazolam }- \\
0.05 \mathrm{mg} / \mathrm{kg} \\
\text { w/fentanyl } \\
0.5 \mathrm{mcg} / \mathrm{kg} \\
\\
\text { Ketamine } \\
0.25 \mathrm{mg} / \mathrm{kg} \\
\text { w/fentanyl } \\
0.5 \mathrm{mcg} / \mathrm{kg}\end{array}$ & $\begin{array}{l}\text { completion of } \\
\text { procedure } \\
\text { prior to d/c of } \\
\text { inhalation } \\
\text { agents and } \\
\text { after d/c of } \\
\text { remi }\end{array}$ & $\begin{array}{l}\text { fentanyl } \\
\text { remifentanil } \\
\text { atropine } \\
\text { TIVA }\end{array}$ & $\begin{array}{l}\text { mean } 6 \\
\text { range } 3 \text { - } \\
10 \\
P A E D>10 \\
=8 \\
\geq 10=8 \\
\geq 15=3 \\
P<0.05\end{array}$ & $\begin{array}{l}\text { Midaz } \\
\text { mean 5 } \\
\text { range 2-15 } \\
\geq 10=6 \\
\geq 15=1 \\
\underline{\text { Ketam }} \\
\text { mean 9 } \\
\text { range 3-20 } \\
\geq 10=18 \\
\geq 15=10 \\
\mathrm{P}<0.05\end{array}$ & $\begin{array}{l}\text { arrival @ } \\
\text { PACU, 5, } \\
10,15 \& 30 \\
\text { min. Mean } \\
\text { PAED } \\
\text { scores } \\
\text { recorded. } \\
\text { Also \# of } \\
\text { pts with } \\
\text { scores } \geq 10 \\
\text { and } 15\end{array}$ & $\begin{array}{l}\text { not } \\
\text { specified }\end{array}$ & $\begin{array}{l}\text { Prop }= \\
17.0 \pm \\
2.1 \\
\text { Midaz }= \\
21.2 \pm \\
3.5 \\
\text { Ketami } \\
\text { ne } \\
19.4 \pm \\
5.2\end{array}$ & $\begin{array}{l}\text { Prop }= \\
27.3 \pm \\
4.9 \\
\text { Midaz }= \\
29.3 \pm \\
6.2 \\
\text { Ketami } \\
\text { ne } \\
30.4 \pm \\
3.3\end{array}$ & LMA & $\begin{array}{l}\text { ketamine } \\
\text { group }=2 \\
\text { patient with } \\
\text { hallucin- } \\
\text { ations and } \\
\text { night } \\
\text { terrors }\end{array}$ \\
\hline
\end{tabular}




\begin{tabular}{|c|c|c|c|c|c|c|c|c|c|c|c|c|c|}
\hline $\mathrm{g}$ & Kim, 2012 & $1 \mathrm{mg} / \mathrm{kg}$ & $\begin{array}{l}\text { saline - } \\
\text { unspecified } \\
\text { amount } \\
\text { fentanyl- } \\
1 \mathrm{mcg} / \mathrm{kg}\end{array}$ & $\begin{array}{l}\text { completion of } \\
\text { surgery after } \\
d / c \text { of sevo }\end{array}$ & $\begin{array}{l}\text { Caudal } \\
\text { block with } \\
0.5 \% \\
\text { bupivacaine } \\
\text { Sevo 2-2.5\% }\end{array}$ & $\begin{array}{l}\text { mean }= \\
4.3 \\
\mathrm{P}<0.001\end{array}$ & $\begin{array}{l}\text { saline }=9 \\
\text { fent }=4.9 \\
\mathrm{P}<0.001\end{array}$ & $\begin{array}{l}\text { arrival to } \\
\text { PACU and } \\
5 \text { min } \\
\text { intervals } \\
\text { for } 1^{\text {st }} 30 \\
\text { min, mean } \\
\text { scores } \\
\text { evaluated }\end{array}$ & $\begin{array}{l}\text { no } \\
\text { parents } \\
\text { present }\end{array}$ & $\begin{array}{l}\text { Prop = } \\
27.7 \\
\text { Saline = } \\
17.6 \\
\text { Fentany } \\
1 \\
17.6 \\
P<0.001\end{array}$ & $\begin{array}{l}\text { Prop= } \\
37.1 \\
\text { Saline= } \\
33.4 \\
\text { Fentany } \\
1 \\
40.4 \\
\mathrm{P}<0.001\end{array}$ & LMA & $\begin{array}{l}\text { airway } \\
\text { obstruct: } \\
\text { prop (2) } \\
\text { saline (0) } \\
\text { fent (4) } \\
\text { Laryngo- } \\
\text { spasm: } \\
\text { prop (1) } \\
\text { saline (0) } \\
\text { fent (1) } \\
\text { N/V: } \\
\text { prop (4) } \\
\text { saline (2) } \\
\text { fent (17) }\end{array}$ \\
\hline
\end{tabular}




\section{Appendix F-3}

Randomized Control Trial Appraisals

\begin{tabular}{|c|c|c|c|c|c|c|c|c|c|c|}
\hline & $\begin{array}{l}\text { Author, } \\
\text { Year }\end{array}$ & Study Type & $\begin{array}{l}\text { Consent/ } \\
\text { Funding }\end{array}$ & $\begin{array}{l}\text { Inclusion } \\
\text { Criteria }\end{array}$ & $\begin{array}{l}\text { Exclusion } \\
\text { Criteria }\end{array}$ & $\begin{array}{l}\text { Randomizatio } \\
\mathrm{n}\end{array}$ & Attrition & Blinding & Strengths & Limitations \\
\hline $\mathrm{a}$ & $\begin{array}{l}\text { Abu- } \\
\text { Shahwan } \\
, 2008\end{array}$ & $\begin{array}{l}\text { Prospective } \\
\text { Randomized } \\
\text { Double } \\
\text { Blinded }\end{array}$ & $\begin{array}{l}\text { ethics } \\
\text { committee } \\
\text { approval } \\
\text { and parental } \\
\text { consent } \\
\text { no funding } \\
\text { indicated }\end{array}$ & $\begin{array}{l}\text { ASA I-II, } \\
2-7 \text { yo, } \\
\text { elective } \\
\text { MRI as } \\
\text { outpatient } \\
\text { with GA, } \\
\text { normal } \\
\text { cognitive } \\
\text { function }\end{array}$ & $\begin{array}{l}\text { patients were } \\
\text { excluded } \\
\text { based on } \\
\text { cognitive } \\
\text { disorders, } \\
\text { developmenta } \\
1 \text { delay and } \\
\text { the need for } \\
\text { sedatives } \\
\text { prior to } \\
\text { induction }\end{array}$ & $\begin{array}{l}\text { randomized } \\
\text { into two } \\
\text { treatment } \\
\text { groups using } \\
\text { random } \\
\text { number } \\
\text { generator }\end{array}$ & $\begin{array}{l}1 \text { patient lost } \\
\text { related to } \\
\text { administration } \\
\text { of propofol to } \\
\text { placebo group }\end{array}$ & $\begin{array}{l}\text { intervention- } \\
\text { al and } \\
\text { placebo } \\
\text { administered } \\
\text { by } \\
\text { anesthesia } \\
\text { assistant, } \\
\text { EA } \\
\text { evaluated by } \\
\text { blinded } \\
\text { recovery RN }\end{array}$ & $\begin{array}{l}\text { Generalizable - } \\
\text { MRI is a non } \\
\text { painful } \\
\text { procedure and } \\
\text { study was able } \\
\text { to exclude pain } \\
\text { as contributing } \\
\text { factor to EA } \\
\text { double blinded } \\
\text { P<0.05, U-test, } \\
\text { fisher's exact } \\
\text { test }\end{array}$ & $\begin{array}{l}\text { PAED } \\
\text { scoring } \\
\text { difficult in } \\
\text { pediatric eye } \\
\text { surgery r/t } \\
\text { inability to } \\
\text { make eye } \\
\text { contact, } \\
\text { increased } \\
\text { difficulty } \\
\text { with bilateral } \\
\text { procedures }\end{array}$ \\
\hline
\end{tabular}




\begin{tabular}{|c|c|c|c|c|c|c|c|c|c|c|}
\hline $\mathrm{b}$ & $\begin{array}{l}\text { Costi, } \\
2015\end{array}$ & $\begin{array}{l}\text { Prospective } \\
\text { Randomized } \\
\text { Double } \\
\text { Blinded } \\
\text { Control } \\
\text { Trial }\end{array}$ & $\begin{array}{l}\text { ethics } \\
\text { committee } \\
\text { approval \& } \\
\text { registered } \\
\text { with } \\
\text { Austrailian } \\
\text { and NZ } \\
\text { clinical trial } \\
\text { registry, } \\
\text { informed } \\
\text { parental } \\
\text { consent } \\
\text { Funding- } \\
\text { society for } \\
\text { paediatric } \\
\text { anaesthesia } \\
\text { in New } \\
\text { Zealand and } \\
\text { Austrailia }\end{array}$ & $\begin{array}{l}\text { ASA I-II, } \\
\text { age 1-12, } \\
\text { undergoing } \\
\text { MRI under } \\
\text { GA }\end{array}$ & $\begin{array}{l}\text { performance } \\
\text { of painful } \\
\text { procedure, } \\
\text { pupillary } \\
\text { dilation, } \\
\text { allergy to } \\
\text { propofol or } \\
\text { eggs, family } \\
\text { history of MH }\end{array}$ & $\begin{array}{l}\text { randomly } \\
\text { assigned to } \\
\text { control or } \\
\text { interventional } \\
\text { group by } \\
\text { computer } \\
\text { generated } \\
\text { numbers }\end{array}$ & $\begin{array}{l}\text { use of } \\
\text { CONSORT } \\
\text { flow diagram } \\
\text { to report } \\
\text { sample } \\
\text { selection } \\
12 \text { initially } \\
\text { lost for } \\
\text { refusal to } \\
\text { participate } \\
\text { no } \\
\text { participants } \\
\text { lost after } \\
\text { randomization } \\
\text { and allocation }\end{array}$ & $\begin{array}{l}\text { outcome } \\
\text { assessor was } \\
\text { blinded to } \\
\text { intervention }\end{array}$ & $\begin{array}{l}\text { large patient } \\
\text { sample } \\
\text { provides } \\
\text { insight on EA } \\
\text { in patients } \\
\text { undergoing } \\
\text { non-painful } \\
\text { procedures } \\
\text { double blinded } \\
\text { use of } \\
\text { CONSORT } \\
\text { flow diagram } \\
\text { P<0.001 for } \\
\text { PAED scores } \\
\text { Data check } \\
\text { with Shapiro } \\
\text { wilks test }\end{array}$ & $\begin{array}{l}\text { some } \\
\text { patients were } \\
\text { administered } \\
\text { propofol at } \\
\text { induction } \\
\text { higher } \\
\text { propofol } \\
\text { dose of } \\
3 \mathrm{mg} / \mathrm{kg} \\
\text { administered } \\
\mathrm{P}=0.573 \text { for } \\
\text { hospital } \\
\text { discharge } \\
\text { time - } \\
\text { weakened } \\
\text { signficance }\end{array}$ \\
\hline $\mathrm{c}$ & Ali, 2013 & $\begin{array}{l}\text { Prospective } \\
\text { Randomized } \\
\text { Double } \\
\text { Blinded }\end{array}$ & $\begin{array}{l}\text { IRB } \\
\text { approval } \\
\text { and written } \\
\text { consent } \\
\text { from parents } \\
\text { no funding } \\
\text { indicated }\end{array}$ & $\begin{array}{l}\text { ASA I-II, } \\
2-6 \text { yo, } \\
\text { elective } \\
\text { adenotons- } \\
\text { illectomy }\end{array}$ & $\begin{array}{l}\text { excluded } \\
\text { mental } \\
\text { disease, neuro } \\
\text { disease and } \\
\text { treatment with } \\
\text { sedatives, full } \\
\text { stomach or } \\
\text { need for RSI }\end{array}$ & $\begin{array}{l}\text { randomized } \\
\text { into } 3 \text { groups } \\
\text { using } \\
\text { computerized } \\
\text { generated } \\
\text { randomization } \\
\text { table }\end{array}$ & $\begin{array}{l}\text { all patients } \\
\text { that were } \\
\text { enrolled } \\
\text { completed the } \\
\text { study }\end{array}$ & $\begin{array}{l}\text { IV meds } \\
\text { prepared } \\
\text { and hidden } \\
\text { behind } \\
\text { drapes. } \\
\text { Anesthesia } \\
\text { provider } \\
\text { administered } \\
\text { meds, } 2^{\text {nd }} \\
\text { blinded } \\
\text { provider } \\
\text { assessed } \\
\text { PAED }\end{array}$ & $\begin{array}{l}\text { T\&A surgery } \\
\text { commonly } \\
\text { performed in } \\
\text { pediatric } \\
\text { population. } \\
\text { Demonstrated } \\
\text { decreased } \\
\text { PAED scores } \\
\text { among } \\
\text { propofol and } \\
\text { precedex } \\
\text { groups } \\
\text { double blinded }\end{array}$ & $\begin{array}{l}\text { CONSORT } \\
\text { not used in } \\
\text { study - } \\
\text { unclear } \\
\text { original } \\
\text { participant } \\
\text { selection and } \\
\text { attrition }\end{array}$ \\
\hline
\end{tabular}




\begin{tabular}{|c|c|c|c|c|c|c|c|c|c|c|}
\hline $\mathrm{d}$ & $\begin{array}{l}\text { Lee, } \\
2010\end{array}$ & $\begin{array}{l}\text { Prospective } \\
\text { Randomized } \\
\text { Double } \\
\text { Blinded } \\
\text { Control } \\
\text { Trial }\end{array}$ & $\begin{array}{l}\text { IRB } \\
\text { approval } \\
\text { and written } \\
\text { parental } \\
\text { consent } \\
\text { no funding } \\
\text { indicated }\end{array}$ & $\begin{array}{l}\text { ASA I, 3-8 } \\
\text { yo, elective } \\
\text { adenotonsi } \\
\text {-llectomy }\end{array}$ & $\begin{array}{l}\text { mental } \\
\text { disease,neuro } \\
\text { disease, } \\
\text { sedative } \\
\text { medication } \\
\text { usage }\end{array}$ & $\begin{array}{l}\text { randomly } \\
\text { assigned to } \\
\text { one of two } \\
\text { groups by } \\
\text { computer } \\
\text { generated } \\
\text { numbers }\end{array}$ & $\begin{array}{l}1 \text { patient from } \\
\text { propofol } \\
\text { group } \\
\text { dropped } \mathrm{r} / \mathrm{t} \\
\text { ST depression } \\
\text { on EKG, } 1 \\
\text { patient from } \\
\text { saline group } \\
\text { related to } \\
\text { bleeding on } \\
\text { extubation }\end{array}$ & $\begin{array}{l}\text { blinded } \\
\text { anesthesia } \\
\text { provider } \\
\text { assessed } \\
\text { PAED } \\
\text { scores post- } \\
\text { operatively }\end{array}$ & $\begin{array}{l}\text { double blinded } \\
\text { procedure with } \\
\text { high incidence } \\
\text { of EA }\end{array}$ & $\begin{array}{l}\text { difficulty } \\
\text { determining } \\
\text { if pain or } \\
\text { delirium } \\
\text { no } \\
\text { significant } \\
\text { decrease in } \\
\text { EA within } \\
\text { propofol } \\
\text { group } \\
\text { small sample }\end{array}$ \\
\hline e & $\begin{array}{l}\text { Auoad, } \\
2007\end{array}$ & $\begin{array}{l}\text { Prospective } \\
\text { Randomized } \\
\text { Double } \\
\text { Blinded } \\
\text { Control } \\
\text { Trial }\end{array}$ & $\begin{array}{l}\text { IRB } \\
\text { approval } \\
\text { and written } \\
\text { parental } \\
\text { consent } \\
\text { no funding } \\
\text { indicated }\end{array}$ & $\begin{array}{l}\text { ASA I-II, } \\
\text { 2-6 yo, } \\
\text { elective } \\
\text { strabismus } \\
\text { surgery } \\
\text { under GA }\end{array}$ & $\begin{array}{l}\text { Mental } \\
\text { disease, neuro } \\
\text { disease, } \\
\text { sedatives, full } \\
\text { stomach, RSI }\end{array}$ & $\begin{array}{l}\text { randomly } \\
\text { assigned into } \\
\text { propofol or } \\
\text { control group } \\
\text { using } \\
\text { computer } \\
\text { generated } \\
\text { numbers }\end{array}$ & $\begin{array}{l}3 \text { patients } \\
\text { were excluded } \\
\text { from saline } \\
\text { group } \mathrm{r} / \mathrm{t} \\
\text { incomplete } \\
\text { data } \\
\text { collection }\end{array}$ & $\begin{array}{l}\text { anesthesia } \\
\text { provider that } \\
\text { collected } \\
\text { data was } \\
\text { blinded to } \\
\text { which } \\
\text { intervention } \\
\text { was } \\
\text { administered }\end{array}$ & $\begin{array}{l}\text { Generalizabilit } \\
\text { y - eye } \\
\text { surgeries } \\
\text { common with } \\
\text { pediatric } \\
\text { population, } \\
\text { increased risk } \\
\text { of PONV and } \\
\text { EA } \\
\mathrm{P}=.004 \\
\text { double blinded }\end{array}$ & $\begin{array}{l}\text { PAED } \\
\text { scoring } \\
\text { difficult in } \\
\text { pediatric eye } \\
\text { surgery r/t } \\
\text { inability to } \\
\text { make eye } \\
\text { contact, } \\
\text { increased } \\
\text { difficulty } \\
\text { with bilateral } \\
\text { procedures } \\
\text { CONSORT } \\
\text { flow diagram } \\
\text { not used - no } \\
\text { specific } \\
\text { reporting of } \\
\text { participant } \\
\text { selection and } \\
\text { attrition }\end{array}$ \\
\hline
\end{tabular}




\begin{tabular}{|c|c|c|c|c|c|c|c|c|c|c|}
\hline $\mathrm{f}$ & $\begin{array}{l}\text { Chen, } \\
2010\end{array}$ & $\begin{array}{l}\text { Prospective } \\
\text { Randomized } \\
\text { Double } \\
\text { Blinded } \\
\text { Control } \\
\text { Trial }\end{array}$ & $\begin{array}{l}\text { ethics } \\
\text { committee } \\
\text { approval } \\
\text { and parental } \\
\text { consent } \\
\text { no funding } \\
\text { indicated }\end{array}$ & $\begin{array}{l}\text { ASA I-II, } \\
1-7 \text { yo, } \\
\text { elective } \\
\text { cataract } \\
\text { surgery }\end{array}$ & $\begin{array}{l}\text { behavioral } \\
\text { problems \& } \\
\text { physical } \\
\text { developmenta } \\
1 \text { delay }\end{array}$ & $\begin{array}{l}\text { randomly } \\
\text { assigned to } \\
\text { one of three } \\
\text { groups by } \\
\text { means of } \\
\text { computer } \\
\text { generated } \\
\text { numbers }\end{array}$ & $\begin{array}{l}\text { no patients } \\
\text { were lost after } \\
\text { initial } \\
\text { enrollment }\end{array}$ & $\begin{array}{l}\text { blinded } \\
\text { recovery } \\
\text { nurse } \\
\text { assessed } \\
\text { PAED } \\
\text { scores }\end{array}$ & $\begin{array}{l}\text { double blinded } \\
\text { minimal pain } \\
\text { involved in } \\
\text { procedure - } \\
\text { eliminate pain } \\
\text { as cause of EA } \\
\text { P }<0.05 \text { on } \\
\text { PAED scores }\end{array}$ & $\begin{array}{l}\text { lack of } \\
\text { placebo } \\
\text { group } \\
\text { fentanyl } \\
\text { administered } \\
\text { to all patients } \\
\text { vision } \\
\text { affecting } \\
\text { PAED } \\
\text { assessment } \\
\text { no statistical } \\
\text { analysis of } \\
\text { emergence } \\
\text { times or } \\
\text { discharge } \\
\text { time }\end{array}$ \\
\hline $\mathrm{g}$ & $\begin{array}{l}\text { Kim, } \\
2012\end{array}$ & $\begin{array}{l}\text { Prospective } \\
\text { Randomized } \\
\text { Double } \\
\text { Blinded } \\
\text { Control } \\
\text { Trial }\end{array}$ & $\begin{array}{l}\text { IRB } \\
\text { approval } \\
\text { and national } \\
\text { registration } \\
\text { parental } \\
\text { consent } \\
\text { Funding by } \\
\text { departmenta } \\
1 \text { monies }\end{array}$ & $\begin{array}{l}\text { ASA I-II, } \\
18-72 \\
\text { months, } \\
\text { elective } \\
\text { inguinal } \\
\text { hernia } \\
\text { surgery in } \\
\text { ambulatory } \\
\text { care setting }\end{array}$ & $\begin{array}{l}\text { developmenta } \\
1 \text { delay, } \\
\text { psychologic } \\
\text { or neurologic } \\
\text { disorders, } \\
\text { abnormal } \\
\text { airway, } \\
\text { reactive } \\
\text { airway } \\
\text { disease, } \\
\text { history of } \\
\text { general } \\
\text { anesthesia }\end{array}$ & $\begin{array}{l}\text { randomly } \\
\text { assigned to } \\
\text { one of three } \\
\text { groups by } \\
\text { internet site } \\
\text { program }\end{array}$ & $\begin{array}{l}60 \text { patients } \\
\text { were lost } \\
\text { during trial } \\
\text { related to } \\
\text { airway } \\
\text { complications } \\
\text {, severe } \\
\text { agitation at } \\
\text { induction and } \\
\text { failure to } \\
\text { receive } \\
\text { intervention }\end{array}$ & $\begin{array}{l}\text { syringes } \\
\text { wrapped in } \\
\text { foil by } \\
\text { investigator } \\
\text { not involved } \\
\text { with } \\
\text { anesthesia, } \\
\text { assessors of } \\
\text { PAED } \\
\text { scores were } \\
\text { blinded }\end{array}$ & $\begin{array}{l}\text { double blinded } \\
\text { non-painful } \\
\text { procedure }\end{array}$ & $\begin{array}{l}\text { inguinal } \\
\text { hernia repair } \\
\text { has low } \\
\text { incidence of } \\
\text { EA } \\
\text { patients with } \\
\text { preoperative } \\
\text { anxiety } \\
\text { excluded - } \\
\text { contributor } \\
\text { to EA }\end{array}$ \\
\hline
\end{tabular}




\section{Appendix G-1}

Abu-Shahwan, I. (2008). Effect of propofol on emergence behavior in children after sevoflurane general anesthesia. Pediatric Anesthesia, 18, 55-59.

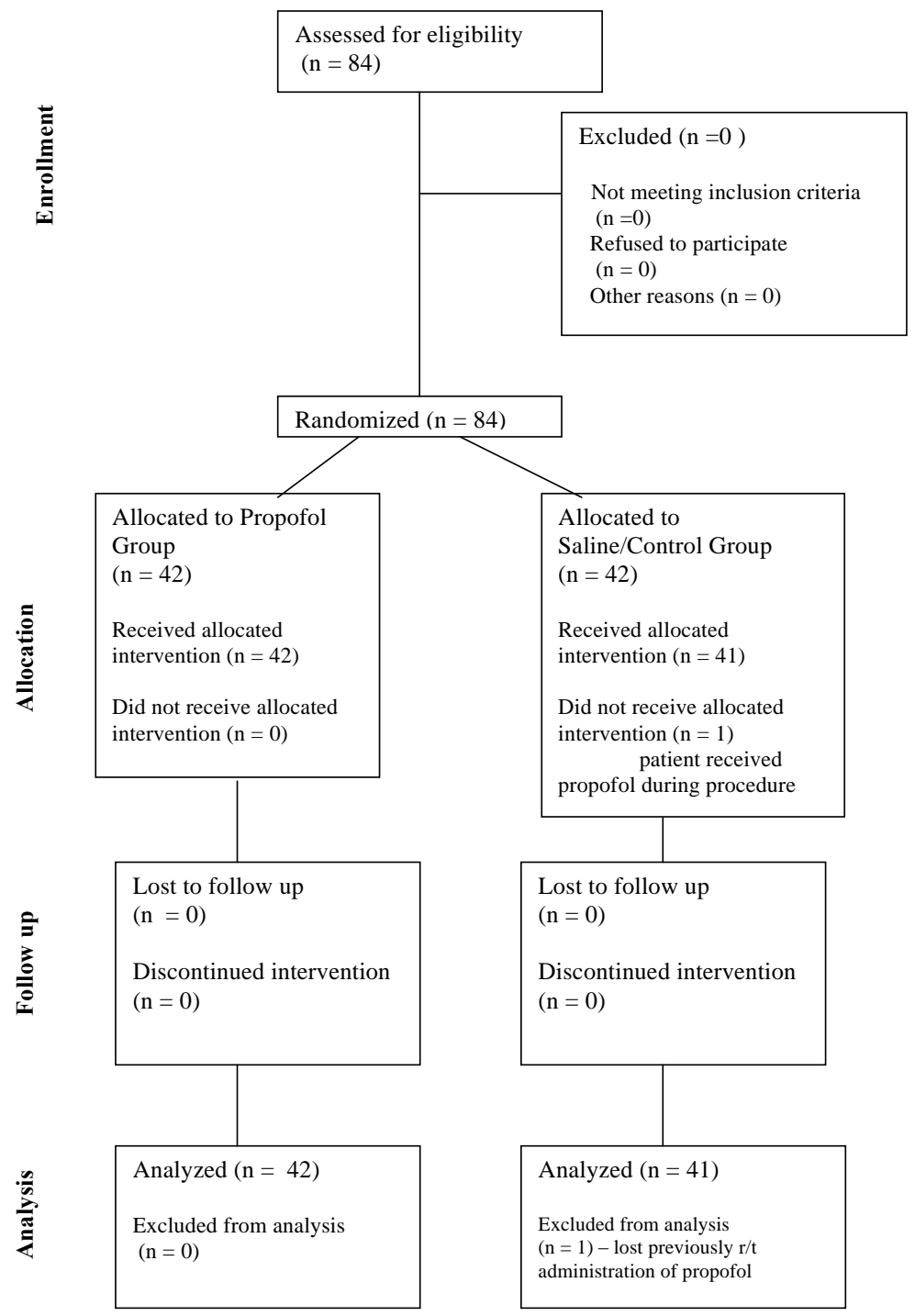




\section{Appendix G-2}

Costi, et al. (2015). Transition to propofol after sevoflurane anesthesia to prevent emergence agitation: a randomized controlled trial. Pediatric Anesthesia, 5 (25), $517-523$.

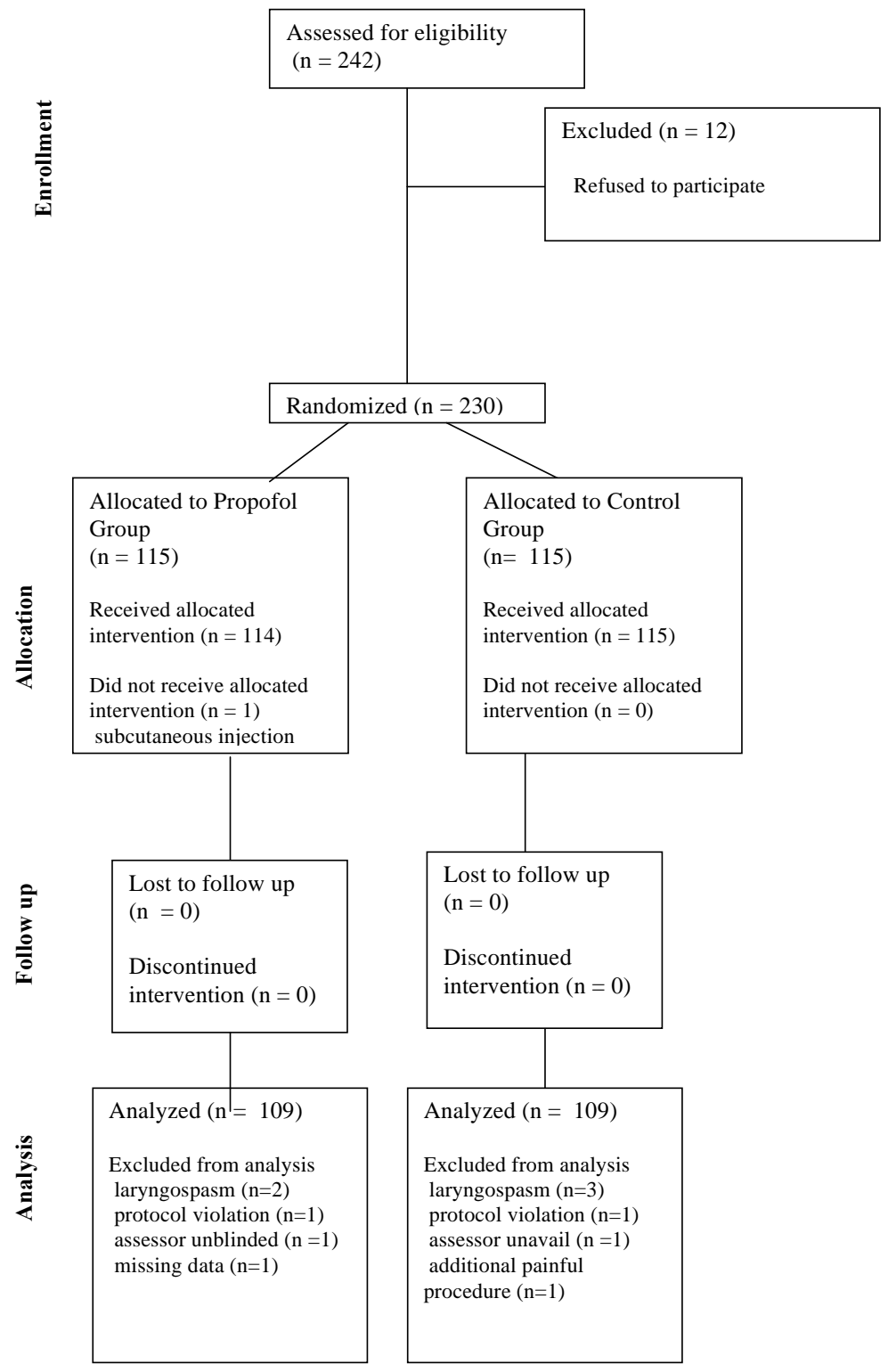




\section{Appendix G-3}

Ali, M.A., \& Abdellatif, A.A. (2013). Prevention of sevoflurane related emergence agitation in children undergoing adenotonsillectomy: A comparison of dexmedetomidine and propofol. Saudi Journal of Anaesthesia, 7 (3), 296-300.

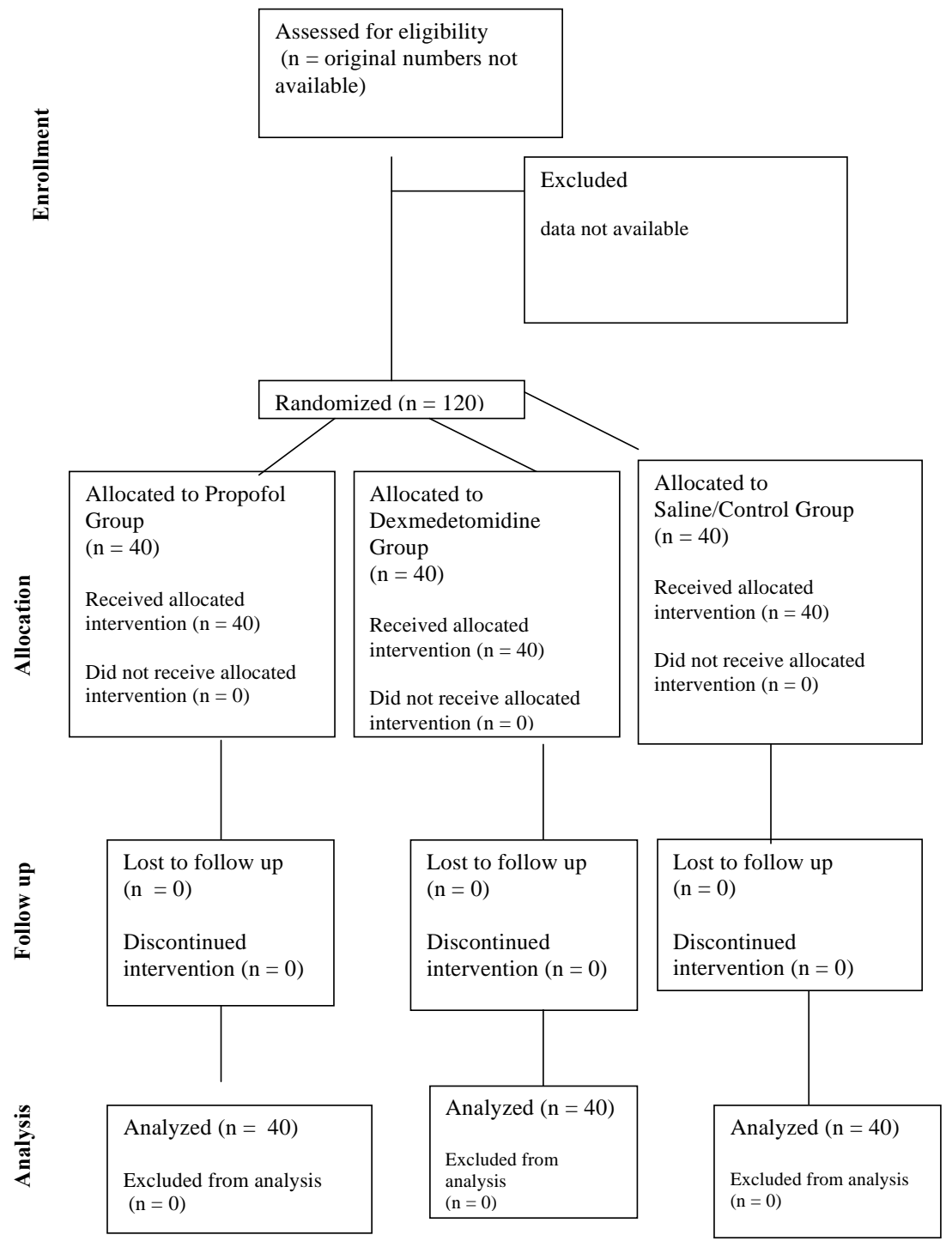




\section{Appendix G-4}

Lee, C.J. et al. (2010). The effect on propofol on emergence agitation in children receiving sevoflurane for adenotonsillectomy. Korean Journal of

Anesthesiology, 2(52), 75-81.

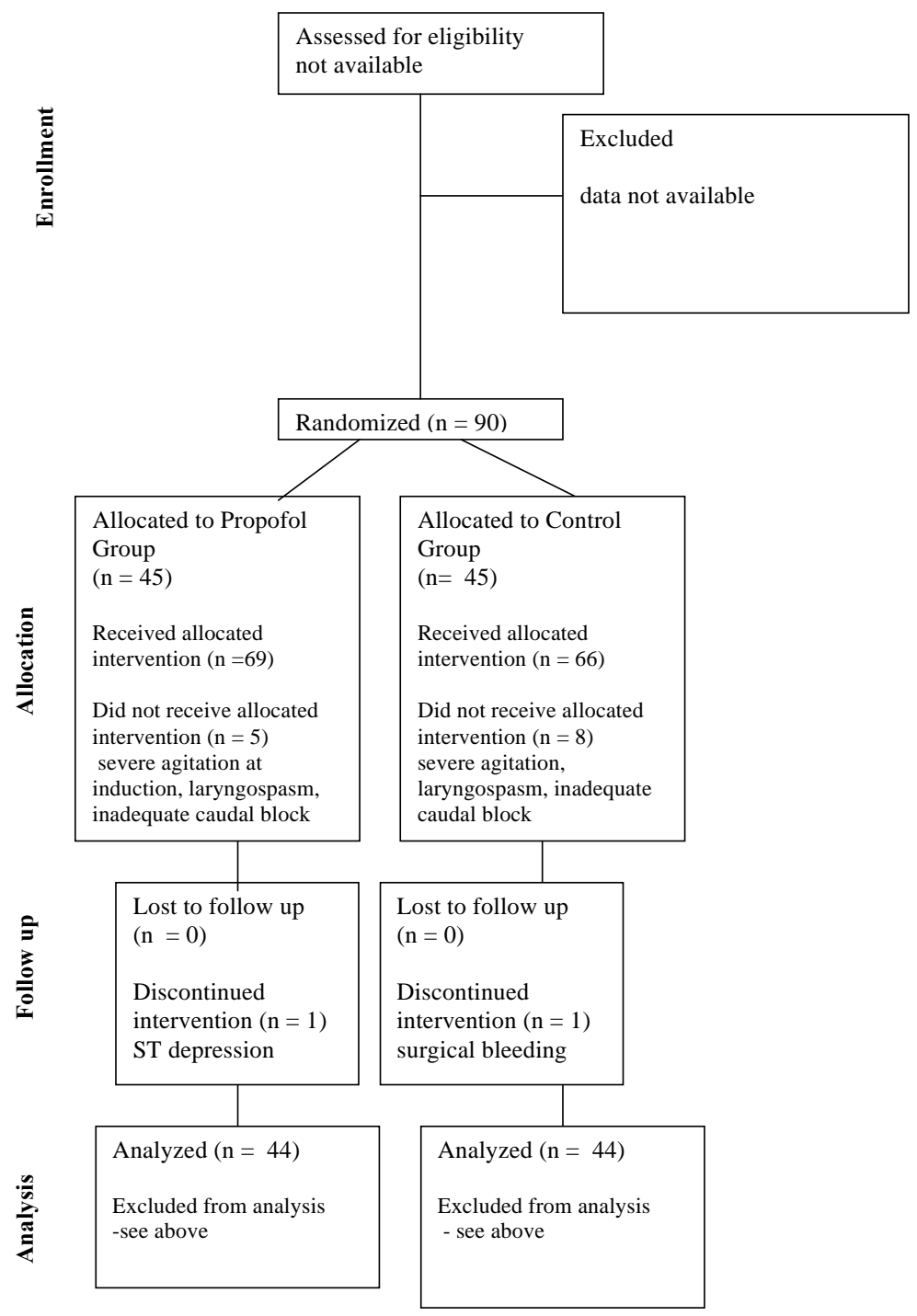




\section{Appendix G-5}

Aouad, M.D. et al (2007). A single dose of propofol at the end of surgery for the prevention of emergence agitation in children undergoing strabismus surgery during sevoflurane anesthesia. Anesthesiology, 107, 733-738

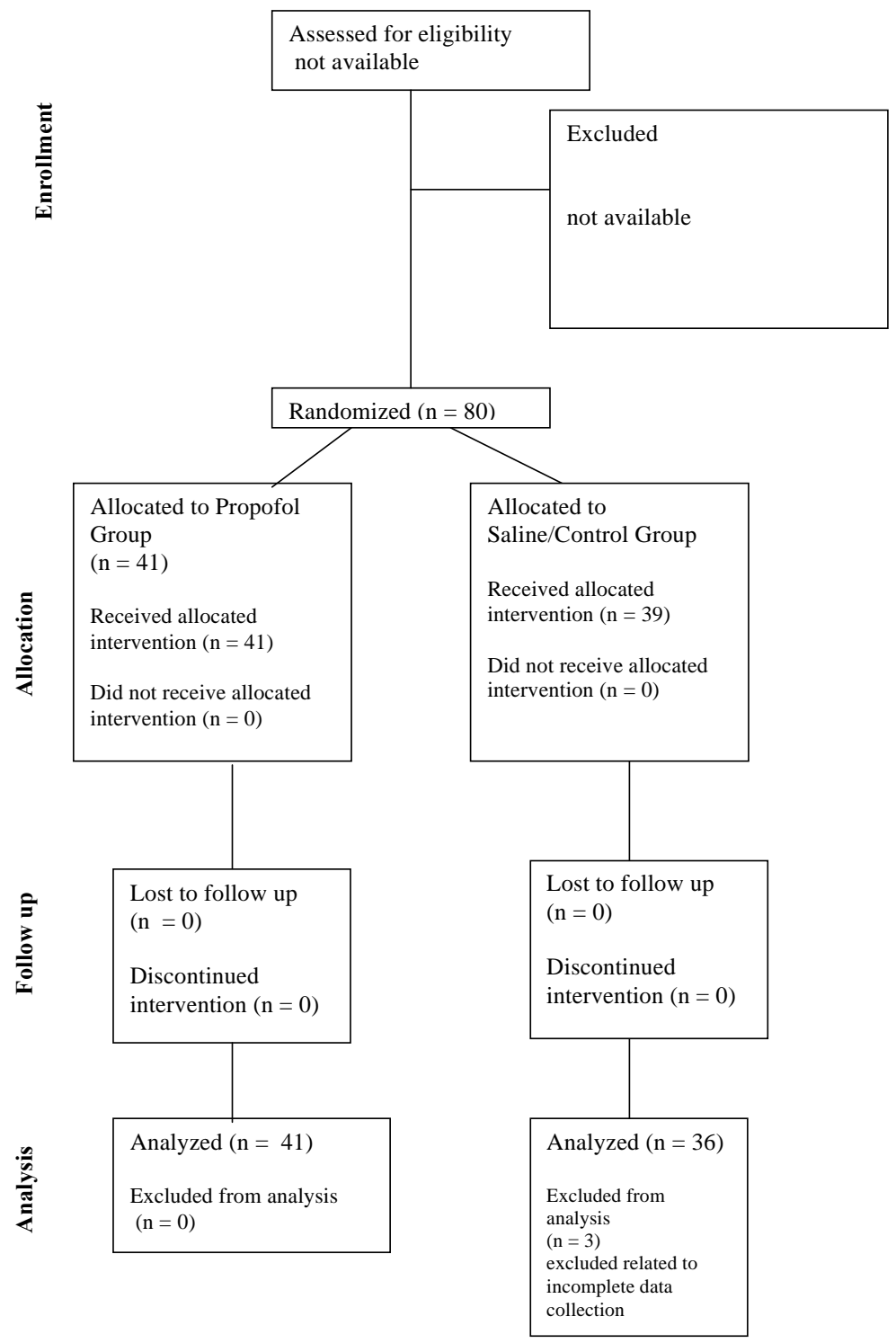




\section{Appendix G-6}

Chen, J. et al. (2010). Emergence agitation after cataract surgery in children: a comparison of midazolam, propofol and ketamine. Pediatric Anesthesia, 20, 873-879.

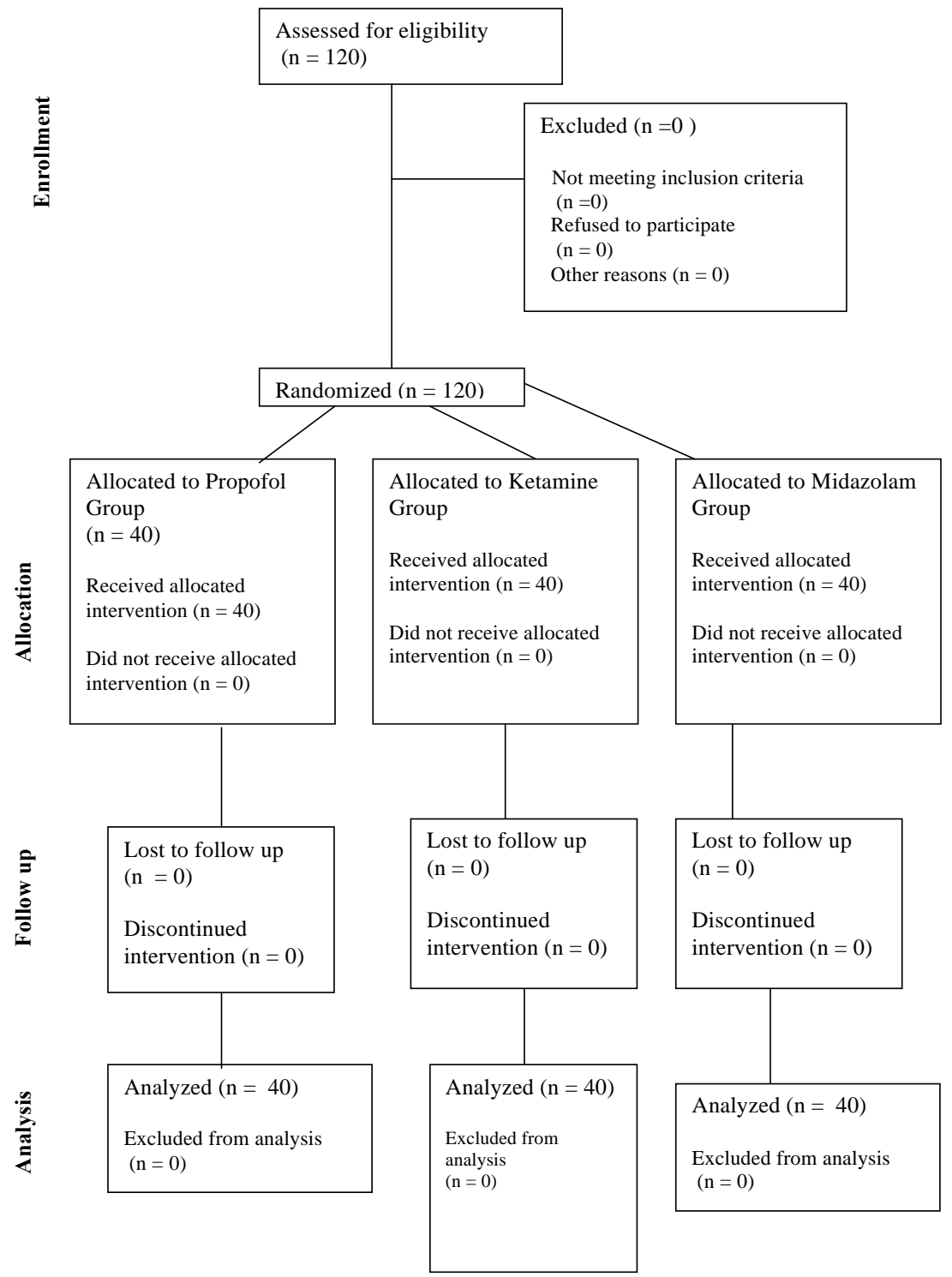




\section{Appendix G-7}

Kim, Y.H. et al. (2012). Prophylactic use of midazolam or propofol at the end of surgery may reduce the incidence of emergence agitation after sevoflurane anaesthesia. Anaesthesia and Intensive Care, 39(5), 904-908.

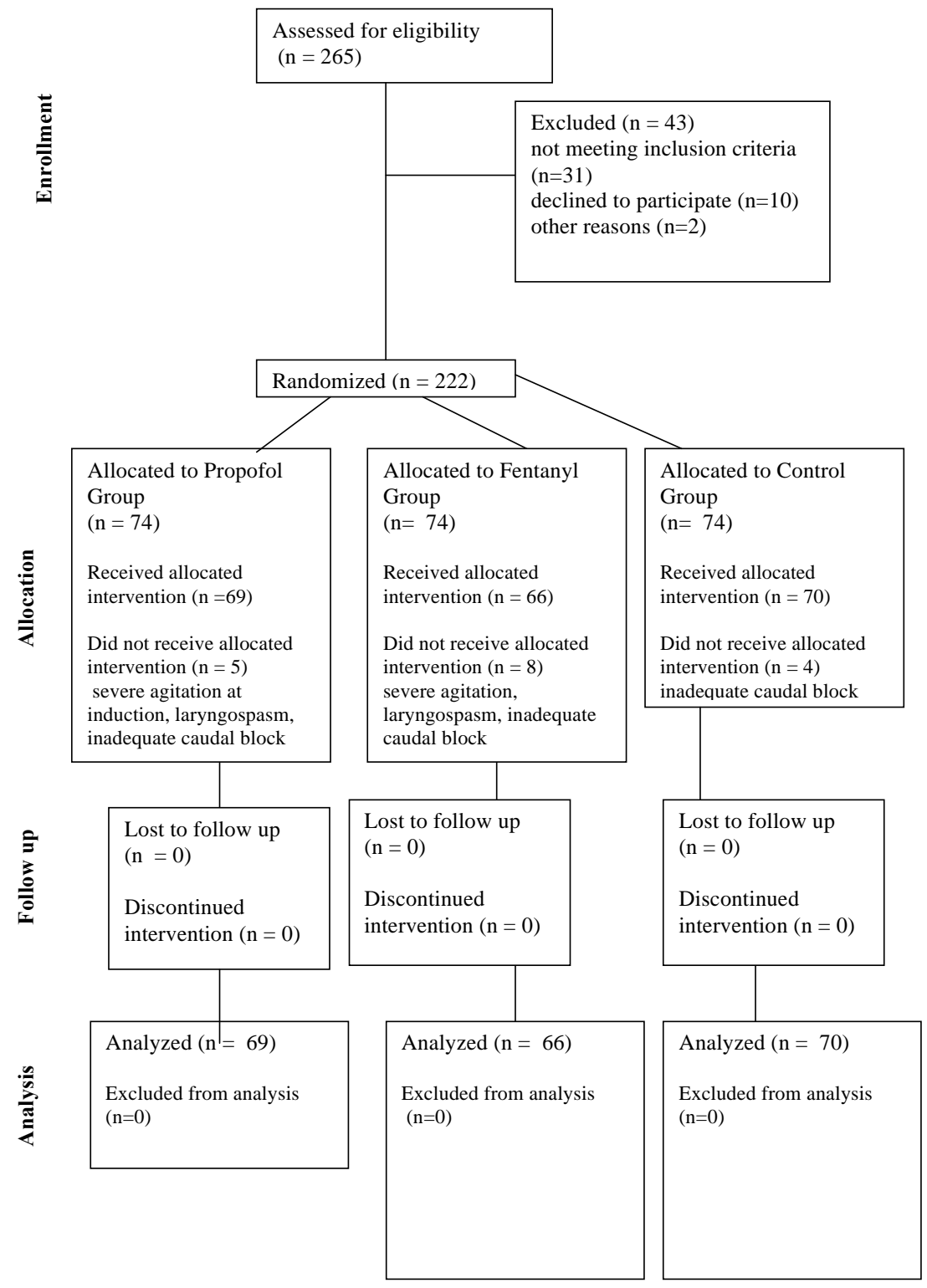




\section{Appendix H}

Cross Study Analysis

\begin{tabular}{|c|c|c|c|c|c|}
\hline & $\begin{array}{l}\text { Author, Year } \\
\text { Type of Procedure }\end{array}$ & $\begin{array}{l}\text { Propofol Group -affect on } \\
\text { PAED scores compared to } \\
\text { control }\end{array}$ & $\begin{array}{l}\text { Propofol Group Affect on } \\
\text { Emergence Times compared } \\
\text { to control (min) }\end{array}$ & $\begin{array}{l}\text { Propofol Group Affect on } \\
\text { Discharge Time compared } \\
\text { to control (min) }\end{array}$ & $\begin{array}{l}\text { Adverse Events in } \\
\text { Propofol group }\end{array}$ \\
\hline 1 & $\begin{array}{l}\text { Abu-Shahwan, } 2008 \\
\text { Outpatient MRI }\end{array}$ & $\begin{array}{l}\text { Propofol = } 7 \\
\text { Control = } 13 \\
\text { (peak PAED) } \\
P<0.05 \\
\text { decrease of } 6\end{array}$ & $\begin{array}{l}\text { Propofol =9 } \pm 3.4 \\
\text { Control }=7 \pm 2.7 \\
P=n s \\
\text { increase of } 2 \mathrm{~min}\end{array}$ & $\begin{array}{l}\text { Propofol = 31.21 } \pm 6.1 \\
\text { Control = 33.4 } \pm 5.8 \\
\mathrm{P}=\mathrm{ns} \\
\text { decrease of } 2.2 \mathrm{~min}\end{array}$ & none \\
\hline 2 & $\begin{array}{l}\text { Costi, } 2015 \\
\text { Outpatient MRI }\end{array}$ & $\begin{array}{l}\text { Propofol }=6 \\
\text { Control }=10 \\
\text { (Peak PAED scores) } \\
P<0.001 \\
\text { decrease by } 4\end{array}$ & $\begin{array}{l}\text { Propofol }=17 \pm 10 \\
\text { Control }=9 \pm 10 \\
\mathrm{P}<0.001 \\
\text { increase by } 8 \mathrm{~min}\end{array}$ & $\begin{array}{l}\text { Propofol }=95 \pm 38 \\
\text { Control }=99 \pm 48 \\
P<0.001 \\
\text { decrease by } 4 \text { min }\end{array}$ & laryngospasm $(\mathrm{n}=1)$ \\
\hline
\end{tabular}




\begin{tabular}{|c|c|c|c|c|c|}
\hline 3 & $\begin{array}{l}\text { Ali, } 2013 \\
\text { Adenotonsillectomy }\end{array}$ & $\begin{array}{l}\text { Propofol = 11.6, 6.6, 5.2, } \\
4.1 \\
\text { Control = 13.7, 8.4, 5.7, } \\
4.2 \\
\text { (PAED scores at T0,5,15 } \\
\text { and 30) } \\
\text { P }<0.05 \\
\text { overall decrease at all time } \\
\text { intervals }\end{array}$ & $\begin{array}{l}\text { Propofol }=12.3 \pm 3.4 \\
\text { Control }=10.7 \pm 2.5 \\
P<0.05 \\
\underline{\text { decrease of } 1.6 \mathrm{~min}}\end{array}$ & $\begin{array}{l}\text { Propofol }=38.5 \pm 5.3 \\
\text { Control }=37.9 \pm 5.5 \\
P<0.05 \\
\text { increase of } 0.6 \mathrm{~min}\end{array}$ & vomiting $(\mathrm{n}=5)$ \\
\hline 4 & $\begin{array}{l}\text { Lee, } 2010 \\
\text { Adenotonsillectomy }\end{array}$ & $\begin{array}{l}\text { Propofol }=12.6,8.2,5.0 \\
\text { Control }=13.8,8.0,4.5 \\
\text { (score at } 5,15 \text { and } 30 \mathrm{~min} \text { ) } \\
\text { P value range from } 0.655- \\
0.672 \\
\text { overall decrease in PAED } \\
\text { scores except at } 15 \text { min } \\
\text { mark }\end{array}$ & $\begin{array}{l}\text { Propofol = } 13.7 \pm 3.8 \\
\text { Control }=12.2 \pm 4.1 \\
\mathrm{P}=0.188 \\
\text { increase by } 1.5 \mathrm{~min}\end{array}$ & $\begin{array}{l}\text { Propofol = } 24.2 \pm 5.0 \\
\text { Control }=25.0 \pm 6.1 \\
\mathrm{P}=0.516 \\
\text { decrease by } 0.8 \mathrm{~min}\end{array}$ & $\begin{array}{l}\text { nausea and } \\
\text { vomiting }(n=4)\end{array}$ \\
\hline 5 & $\begin{array}{l}\text { Auoad, } 2007 \\
\text { Strabismus }\end{array}$ & $\begin{array}{l}\text { Propofol = } 8.6 \pm 3.9 \\
\text { Control = } 11.5 \pm 4.5 \\
\text { (mean PAED) } \\
\mathrm{P}=0.004 \\
\text { decrease of } 2.9\end{array}$ & $\begin{array}{l}\text { Propofol }=23.4 \pm 5.7 \\
\text { Control }=19.7 \pm 5 \\
\mathrm{P}=0.004 \\
\frac{\text { increased emergence time of }}{3.7 \text { min }}\end{array}$ & $\begin{array}{l}\text { Propofol }=34.1 \pm 8.4 \\
\text { Control }=35.9 \pm 8.6 \\
\mathrm{P}=0.68 \\
\text { decreased discharge time of } \\
1.8 \mathrm{~min}\end{array}$ & none \\
\hline
\end{tabular}




\begin{tabular}{|c|c|c|c|c|c|}
\hline 6 & $\begin{array}{l}\text { Chen, } 2010 \\
\text { Cataract }\end{array}$ & $\begin{array}{l}\text { Propofol = } 6 \\
\text { (score in PACU) } \\
\text { No Control group } \\
\mathrm{P}<0.05\end{array}$ & $\begin{array}{l}\text { Propofol }=17.0 \pm 2.1 \\
\text { No Control group } \\
\text { No statistical analysis other } \\
\text { than SD }\end{array}$ & $\begin{array}{l}\text { Propofol }=27.3 \pm 4.9 \\
\text { No Control group } \\
\text { No statistical analysis other } \\
\text { than SD }\end{array}$ & none \\
\hline 7 & $\begin{array}{l}\text { Kim, } 2012 \\
\text { Inguinal Hernia }\end{array}$ & $\begin{array}{l}\text { Propofol }=4.3 \\
\text { Control }=9 \\
\text { (mean PAED score) } \\
\mathrm{P}<0.001 \\
\text { decrease by } 4.7\end{array}$ & $\begin{array}{l}\text { Propofol }=27.7 \\
\text { Control = } 17.6 \\
P<0.001 \\
\text { increase by } 10.1 \mathrm{~min}\end{array}$ & $\begin{array}{l}\text { Propofol = } 37.1 \\
\text { Control }=33.4 \\
P<0.001 \\
\text { increase by } 3.7 \mathrm{~min}\end{array}$ & $\begin{array}{l}\text { airway obstruction } \\
(\mathrm{n}=2) \\
\text { laryngospasm }(\mathrm{n}=1) \\
\text { nausea/vomiting } \\
(\mathrm{n}=2)\end{array}$ \\
\hline
\end{tabular}

